\title{
The Effect of Housing and Stock Wealth Losses on Spending in the Great Recession
}

Marco Angrisani, Michael D. Hurd, and Susann Rohwedder

RAND Labor \& Population

WR-1 101

March 2015

This paper series made possible by the NIA funded RAND Center for the Study of Aging (P3OAG012815) and the NICHD funded RAND Population Research Center (R24HD050906).

RAND working papers are intended to share researchers' latest findings and to solicit informal peer review. They have been approved for circulation by RAND Labor and Population but have not been formally edited or peer reviewed. Unless otherwise indicated, working papers can be quoted and cited without permission of the author, provided the source is clearly referred to as a working paper. RAND's publications do not necessarily reflect the opinions of its research clients and sponsors. RAND® is a registered trademark. 


\title{
The Effect of Housing and Stock Wealth Losses on Spending in the Great Recession
}

\author{
Marco Angrisani, Michael Hurd and Susann Rohwedder*
}

March 26, 2015

\begin{abstract}
We use panel data at the household level on a complete inventory of household spending and assets to estimate the spending response to the sharp and largely unexpected declines in house and stock market prices that occurred in the Great Recession. Our data span the period 2001-2011, so that we are able to separate trends in spending from innovations in response to unexpected wealth change. We find the marginal propensity to consume out of an unexpected housing wealth change to be seven cents per dollar, and about four cents per dollar out of financial wealth.
\end{abstract}

The quantitative relationship between an unexpected wealth loss or gain (a wealth shock) and consumption can sharpen our understanding of intertemporal choice: in the absence of constraints, it reveals the choice between present and future consumption and shows how consumption is traded off against other uses of wealth such as leisure; in the presence of constraints, it shows the realized ability to smooth consumption. Further, from a macro perspective, the

*Angrisani: University of Southern California, Center for Economic and Social Research, 635 Downey Way, Los Angeles, CA 90089-3332, marco.angrisani@usc.edu. Hurd: RAND, 1776 Main St, Santa Monica, CA 90401, mhurd@rand.org. Rohwedder: RAND, 1776 Main St, Santa Monica, CA 90401, susannr@rand.org. Acknowledgements: The authors thank the National Institute on Aging for financial support (Grant R01AG035010). 
average response of households to wealth shocks has the potential to exacerbate booms or busts in the economy: windfall gains in the stock or housing market may lead to spending increases, possibly contributing to bubbles in those markets; unanticipated wealth losses may cause spending reductions, adding to the deflationary forces that were responsible for the losses. Consequently, economic policy makers have considerable interest in the consumption response to a wealth shock. The aim of this paper is to use household-level data on wealth changes and spending from before, during, and after the Great Recession to estimate the response of consumption to wealth shocks. The wealth changes were large, which enhances our ability to detect a response, and the changes were plausibly unanticipated, as required by theory. We consider both financial and housing wealth because of different population exposures and because the consumption reactions may differ.

Because of the importance to economic policy, there is an extensive empirical literature about the wealth effects on consumption. Studies based on macro data find that changes in consumption are related to changes in wealth. For example, Slacalek (2009) uses time series data on the change in consumption and the changes in housing and financial wealth across 16 countries to find that the marginal propensity to consume (MPC) out of wealth is about 0.05; that is a gain of one dollar in wealth, whether housing or financial, will increase consumption by about five cents. This response is typical; as summarized by Paiella (2009), "All these studies find that a dollar increase in aggregate wealth leads to an increase in aggregate consumption of 35 cents ..." (p. 955). Several caveats apply, though. Some studies find substantial differences between the response to a housing wealth shock and a financial one, and at least by some estimations, the sensitivity of consumption to unexpected changes in housing wealth is greater (Case et al., 2013). A second issue concerns the timing of the response. Carroll et al. (2011) estimate that the short-run (one-quarter) response of consumption to a housing wealth shock is just 0.02 , whereas the long-run response is 0.09. A third issue is the interpretation of the correlation as causal. Campbell and Cocco (2007), using data from the UK, find that unexpected variations in house prices cause household consumption to change, 
especially among older households. According to Attanasio et al. (2009), however, such estimated relationships are driven by common factors that affect both household consumption and housing wealth.

Empirical analyses based on micro data have been hampered by the lack of suitable data. To quote Paiella: "To capture the dynamic response of consumption to wealth shocks, long panel data would be needed...Overall, the ideal data set to study the effect of changes in wealth on consumption should contain detailed information both on household assets and liabilities, and on the different categories of consumption expenditure" (p. 967). Excepting the data set we will use in this study, we know of no data that satisfy these requirements. A number of studies have been based on imputed household expenditures in the Panel Study of Income Dynamics (Juster et al., 2006; Morris, 2006), which can be constructed in panel over long periods of time by using observations on household wealth stocks and flows. However, this method requires deriving active savings from capital gains calculations that take the difference of observed asset values across adjacent waves and net out asset purchases and sales. This method is likely to amplify the impact of the measurement error in each of those components.

Further, the results from these earlier studies may be quite different from results based on data from the Great Recession, when the wealth shocks were large and in all likelihood unanticipated. Banks et al. (2013) used panel data on dining out and clothing in the population over age 50 as measured in the English Longitudinal Study of Ageing. Spending on these items was declining in panel prior to the recession, and over the course of the recession there was a negative (though small) deviation from that trend. Bottazzi et al. (2013) used data from the Survey on Household Income and Wealth (SHIW) conducted by the Bank of Italy from before, during, and after the recession in Italy. They find that a shock to financial wealth results in a change in total consumption of about five percent of the shock. A caveat to these results comes from the measure of consumption. While the SHIW data have considerable detail on assets, the measures of consumption are limited: annual durable spending is addressed by a single question, as is annual nondurable spending. Such 
broad questions asking about large spending aggregates lead to substantial underestimation of total spending (Hurd et al., 1998). ${ }^{1}$ The SHIW measure in particular underestimates total spending by 24\% (Browning et al., 2009). Because the wealth shocks in the Great Recession would alter total spending by just a few percent, even a modest change in the understatement of spending in these aggregated questions would lead to substantial bias in the measurement of the response of spending to unanticipated wealth changes.

Christelis et al. (2015) used data from an Internet supplement to the Health and Retirement Study that was administered in May - August 2009. That study asked respondents to recollect by how much their total spending had changed in the past year, by what percent the value of various financial assets had changed since September 2008, and by how much their house value had changed since 2006. It would appear that these tasks are even more difficult for a respondent than reporting total spending as in the SHIW, particularly because they involved the recollection of changes in value from specific prior dates. Nonetheless, the authors estimate that the marginal propensity to consume associated with a financial wealth shock was about 0.033 , and out of a housing wealth shock it was about 0.01. Mian and Sufi (2011) find that the rise in U.S. house prices from 2002 to 2006 was accompanied by a strong, $\$ 1.25$ trillion increase in borrowing against higher home values. They suggest that the debt was mainly used to increase consumption. Under this scenario, with the decline in house prices, this source of consumption financing would disappear, potentially leading to a decline in household spending. In a followon paper, Mian et al. (2013) use zip-code level data on auto sales and countylevel data on credit card or debit card purchases handled by MasterCard. They estimate an MPC of 0.05 - 0.07 out of housing wealth.

This paper uses household-level, panel data on spending before, during, and after the Great Recession to estimate the response of household spending to negative wealth shocks induced by the sharp declines in housing and

\footnotetext{
${ }^{1}$ For example in the initial wave of the Survey of Health, Ageing and Retirement in Europe a one-shot total nondurable spending question resulted in measured spending that was deemed to be a substantial underestimation (Browning and Madsen, 2005).
} 
stock market prices. Our main contribution rests on the richness and quality of our data. We use panel data from the Consumption and Activities Mail Survey (CAMS), a sub-study of the Health and Retirement Study. CAMS has a complete inventory of household spending as obtained on 39 categories of spending, thereby permitting us to avoid biases that may result from using partial measures of spending. Exploiting data on income and assets of the same households, including detailed information on real estate and financial assets, we document the declines brought about by the Great Recession in housing and financial wealth, and then estimate the response of household spending to such shocks. Because our data begin well before the recession and extend after it, we are able to control for any trends in spending. Hence, we can disentangle normal changes in household spending, occurring in non-recession times, and departures from the norm due to unexpected wealth variations in recession times. Our main empirical specification, which follows from a standard consumption Euler equation, relates changes in household spending to changes in wealth, permitting unobservable time-invariant household characteristics that are related to the level of spending to be differenced out.

Changes in household wealth observed over time not only reflect variations in house prices and stock market returns, but are also the result of active saving and investment decisions. In order to disentangle exogenous variation in housing wealth due to the economic downturn from variation due to intended individual decisions (e.g., downsizing, remodeling), we instrument housing wealth changes with changes in house prices at the state level. With this, we are able to isolate shocks attributable to the Great Recession from changes due to active individual decisions. Lacking regional variation in stock market prices, we cannot likewise use an IV estimation strategy to infer the elasticity of household spending with respect to changes in the value of financial assets. Instead we use a group approach where we compare average spending and wealth change of stock owners versus non-owners, and how that comparison differs in the Great Recession from other time periods. For the reason of data availability we only use data on individuals age 50 and older. For our purposes this is a good group to focus on because of the mix of as- 
sets they hold: they hold relatively less human capital (future earnings) and more housing and stock wealth than younger persons, and so are more likely to have been affected by the changes in the value of those assets. Within that age group, we explore heterogeneity in the elasticity of household spending to housing and financial wealth shocks by age. Specifically, we separately consider individuals below and above 65 years, the age when most of the HRS cohort members are retired and therefore are isolated from shocks to the labor market.

Our results may be summarized as follows. We document that, at the state level, changes in self-reported house values track closely changes in housing prices at the state level, and that the variation in the change in house values from state to state was substantial. We use this variation as an instrumental variable for housing wealth change in our estimates of the response of consumption to housing wealth. Financial wealth exhibits substantial growth across consecutive waves in non-recession times. For non-stockowners, this rate of growth was halved during the recession, but among stock owners financial wealth decreased by $9 \%$ during the recession. Differences-in-differences estimates show that the decrease in spending experienced by homeowners during the recession was 7.5 percentage points greater than the decrease experienced by non-homeowners. Homeowners in the states with the largest house price declines reduced their spending by 10 percentage points more than those in the states with the smallest house price declines. Analogously, the comparison of stockowners and non-stockowners indicates that the decrease in spending associated with the recession was 4 percentage points larger for stockowners than for non-stockowners. Yet, there is substantial heterogeneity by age. In the 5165-year-old subsample, stockowners experienced a nearly 9.5-percentage-point larger drop in spending than non-stockowners, while there was no appreciable difference in the 66-90-year-old subsample. From the regressions of changes in household spending on changes in housing wealth, we estimate sizeable and statistically significant marginal propensities to consume during the period of the Great Recession. We find a reduction in household spending of about $\$ 7$ for every $\$ 100$ loss in housing wealth and of about $\$ 4$ for every $\$ 100$ loss in 
financial wealth. The spending elasticity to unexpected changes in housing wealth is slightly declining with age and statistically different from zero only for those below the age of 65 . A similar pattern is observed for the elasticity of household spending to financial wealth shocks, although this parameter is less precisely estimated.

\section{Theoretical Background}

To provide a benchmark of the expected response in consumption to wealth shocks, we consider a standard life-cycle model where forward-looking individuals maximize their lifetime utility by deciding how much to consume over a finite time horizon. Considering a constant relative risk aversion utility function and allowing it to be shifted by a number of demographic variables and seasonal factors (Attanasio and Weber, 1995), the log-linearized Euler equation takes the form:

$$
\Delta \log \left(C_{t+1}\right)=k+\theta \Delta Z_{t+1}+u_{t+1},
$$

where the subscript $t$ denotes time, $C_{t+1}$ is consumption, $Z_{t+1}$ a set of demographic variables and seasonal factors, and the error $u_{t+1}$ represents the surprise in consumption growth

$$
u_{t+1}=\Delta \log \left(C_{t+1}\right)-E_{t}\left[\Delta \log \left(C_{t+1}\right)\right],
$$

which is, by construction, uncorrelated with all information available at time $t, E_{t}\left[u_{t+1}\right]=0$ (Hansen and Singleton, 1983).

Equation (2) has been often used in the empirical literature to test some of the implications of the consumption life-cycle model. A test that has received particular attention is the one of the sensitivity of consumption to expected income changes (Flavin, 1981; Campbell, 1987; Campbell and Mankiw, 1989). Equations (1) and (2) imply that changes in income that are predictable on the basis of information available at time $t$ should not have any explanatory power for consumption growth between period $t$ and $t+1$. A similar argument can 
be used for wealth: anticipated changes in wealth at time $t$ should not predict consumption growth between $t$ and $t+1$. Hence, in the following equation

$$
\Delta \log \left(C_{t+1}\right)=k+\theta \Delta Z_{t+1}+\delta \Delta \log \left(W_{t+1}\right)+u_{t+1},
$$

where $\Delta \log \left(W_{t+1}\right)$ represents wealth growth, the parameter $\delta$ should be zero to the extent that wealth changes between time $t$ and $t+1$ are anticipated..$^{2}$ From an empirical standpoint, it is certainly hard to measure what for individuals constitutes expected changes in wealth, and what does not.

One way of testing these implications and estimating the propensity to consume out of wealth shocks is to identify episodes in which wealth changes are mostly unexpected and large enough to likely have long-lasting consequences. This is the approach taken in this paper. Specifically, we will bring equation (3) to the data distinguishing between changes in household wealth that occurred during the Great Recession, which we argue were sizable and largely unanticipated, and those observed before and after the economic turmoil, which were plausibly more in line with individuals expectations.

\section{Data}

The data for our empirical analyses come from the Health and Retirement Study (HRS), a longitudinal survey that is representative of the U.S. population over the age of 50 and their spouses. The HRS conducts core interviews of about 20,000 persons every two years. In addition, the HRS conducts supplementary studies to cover specific topics beyond those covered in the core surveys. The spending data we use in this paper were collected as part of such a supplementary study, the Consumption and Activities Mail Survey (CAMS). High-quality data on household spending are few and far between. A contribution of our paper comes from our use of much richer and more reliable longitudinal spending data than prior studies in this literature, combined with

\footnotetext{
${ }^{2} \mathrm{~A}$ similar equation is used by Souleles (1999) to estimate the response of consumption to income tax refunds and, more recently, by Christelis et al. (2015) to infer the elasticity of consumption to housing and financial wealth.
} 
detailed information on wealth and its components for the same households. Health and Retirement Study Core Interviews

The first wave of the HRS was collected in 1992; interviews were conducted with those born between 1931 and 1941 and their spouses, irrespective of age. The HRS has re-interviewed respondents every two years. Additional cohorts have been added, so that beginning with the 1998 wave the HRS is representative of the entire population over the age of 50. The HRS collects detailed information on the health, labor force participation, economic circumstances, and social well-being of respondents. The survey dedicates considerable time to elicit income and wealth information and thus provides a complete inventory of the financial situation of households. In this study we use demographic and asset and income data from the HRS core waves spanning the years 2002 through 2010.

\section{Consumption and Activities Mail Survey}

CAMS is a mail survey of a random subsample of about 5,000 HRS households. The primary objectives of the CAMS is to elicit a valid and reliable measure of total annual household spending that can be merged with the data collected on the same households in the HRS core interviews. ${ }^{3}$ As discussed in Hurd and Rohwedder (2009), the features of the CAMS survey instrument were chosen to maximize data quality while keeping respondent burden manageable (Details are in the Appendix). The first wave of CAMS was collected in 2001 and, using a longitudinal design, it has been collected every two years since. Questionnaires are sent out in late September or early October. Most questionnaires are returned in October and November. Thus, CAMS 2001 measures total household spending approximately in the year 2001, CAMS 2003 measures total household spending approximately in 2003, and so on. The sample for the first wave of CAMS was drawn from the pool of HRS households that participated in the year 2000 core interview. About 3,800 HRS households responded to the first wave of CAMS. Since year 2001, the CAMS survey has been conducted every odd-numbered year. As refresher co-

\footnotetext{
${ }^{3}$ Copies of the questionnaires are accessible on the HRS website (http://hrsonline.isr.umich.edu/).
} 
horts were inducted into the HRS (in 2004 and 2010), a random subsample was also inducted into CAMS so that CAMS continues to represent the population over 50. Unit response rates to CAMS average about $72 \%$.

Spending in CAMS is measured in 39 categories covering both durables and nondurables. These categories were chosen to match aggregate categories in the Consumer Expenditure Survey (CEX) so as to facilitate comparison and they are meant to be inclusive of total spending. The rate of item nonresponse is low, averaging about 5\%. Although we impute for missing values (see the Appendix for more details), just a small percentage of total spending is from imputation. ${ }^{4}$ The resulting data have proven of high quality in two ways. Firstly, CAMS spending statistics are closely comparable to those reported in the (CEX). With a much smaller number of survey questions, CAMS total spending lies within five percent of that measured in the CEX for the population 55 and older in each of the CAMS waves, except for the first two waves, in which the CAMS estimates ran slightly higher than those in the CEX. Secondly, when using CAMS total spending together with HRS after-tax income data, the match between the implied motion of wealth and observed wealth change is quite close (Hurd and Rohwedder, 2015).

\section{Sample Selection}

In this study we use five waves of CAMS (2003, 2005, 2007, 2009, and 2011) merged with the RAND HRS version M data file. ${ }^{5}$ The number of households in the sample is 6,134. Of these, $83 \%$ are observed for at least three periods, $7 \%$ are observed for two periods, and $10 \%$ for one period only. The total number

\footnotetext{
${ }^{4}$ We use two types of imputations for missing values on single spending categories. For those items for which there is additional information in the adjacent HRS core interviews, we use that to inform the imputations. For example, a missing rent number is imputed as zero if the household reported owning a home in the HRS core interviews. We also check for data patterns that are strongly suggestive of the respondent having entered an amount in the wrong column of the questionnaire, e.g., if the annualized utility amount is 12 times that in the previous or subsequent wave. These imputations are more detailed than those underlying the RAND-CAMS data, so our data and the RAND-CAMS data are not exactly the same.

${ }^{5}$ After the first wave of CAMS the survey questionnaire was revised somewhat, adding some spending categories and adjusting the recall period for several other categories. Because longitudinal consistency of the data is important in our analytical design, we do not use the first wave of CAMS in our analysis.
} 
of observations at our disposal is 18,830. We drop respondents below the age of 40 and above the age of 90 . This leaves us with 5,993 households and 18,189 observations. We use the CAMS respondent (and his/her characteristics) if he/she is between 51 and 90 years of age, and the CAMS respondent's spouse whenever the CAMS respondent is younger than $51 .^{6}$

Key Analysis Variables

Our measure of household spending is total outlay. ${ }^{7}$ Housing wealth is the gross self-reported value of the primary residence. Financial wealth is the sum of stocks, bonds, certificates of deposit, and checking/saving accounts. All other variables used in the analysis are basic demographics from the HRS core interview (e.g., age, education, marital status, health status, work status, total household income, etc.). Monetary measures are expressed in 2011 dollars using the Consumer Price Index of the Bureau of Labor Statistics. We use the state- and national-level All-Transactions House Price Indices published by the Federal Housing Finance Agency (FHFA) and the state-level unemployment rate published by the Bureau of Labor Statistics, both with quarterly frequency. Further details about these indices and others used in the analysis are provided in the text below.

\section{Changes in Household Wealth and Spending}

Figure 1 shows the evolution of the unemployment rate, house prices and stock prices in the U.S. over the decade 2002-2012, relative to their value in January 2002. The labor, housing, and stock markets are the three sectors of the economy that were most affected by the Great Recession. Nationwide, the unemployment rate was below $6 \%$ in the first quarter of 2002, decreased to $4.5 \%$ by the second quarter of 2007 , and increased to $9.9 \%$ in the third quarter of 2009. House prices steadily increased between 2002 and 2007 up to

\footnotetext{
${ }^{6}$ In a couple, the CAMS respondent is assigned at random.

${ }^{7}$ Data limitations prevent us from measuring the flow of consumption services from durables as accurately as spending, so we study the response of spending to wealth shocks, and refer to spending and consumption interchangeably.
} 


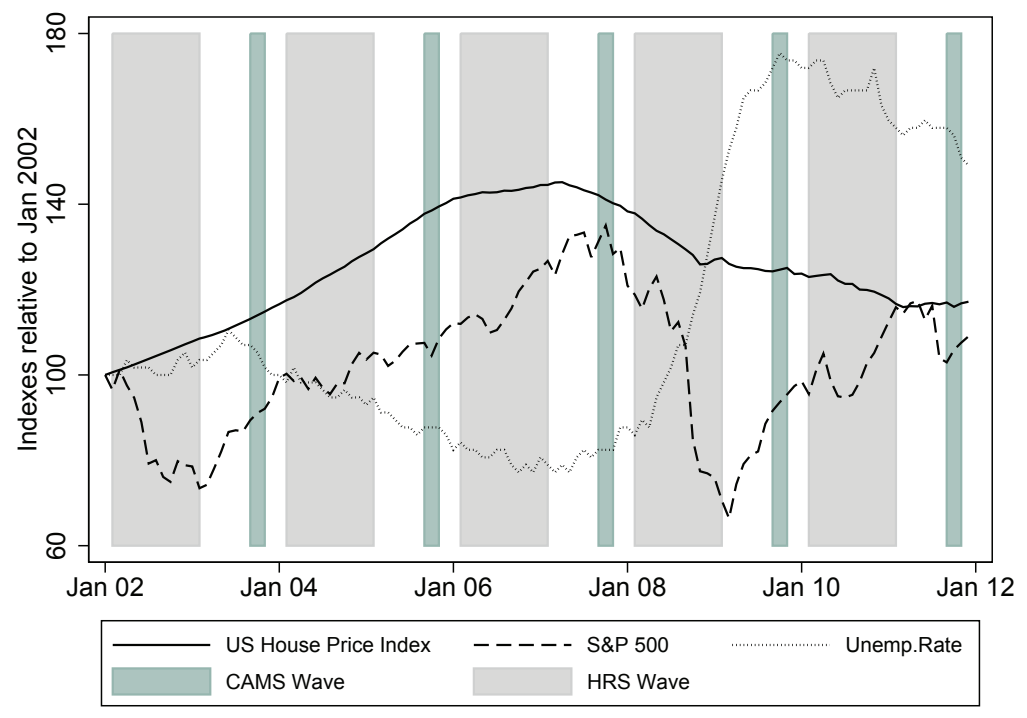

Figure 1: National Indices 2002-2012

a $40 \%$ gain, and decreased by $20 \%$ thereafter. The evolution of the Standard \& Poor's 500 index mimics a roller-coaster ride. Share prices appreciated by $30 \%$ between 2004 and 2007, lost $45 \%$ of their value by the first quarter of 2009, and came near their pre-crisis level in 2011. Figure 1 also shows the timing of all HRS and CAMS waves fielded during this period. The economic situation at the time of interview varied greatly over the waves, particularly in the waves surrounding the recession. House prices were near their peak during both the HRS 2006 and CAMS 2007 interview periods and then declined substantially by the next waves of HRS 2008 and CAMS 2009. Stock prices were still increasing during HRS 2006; the third wave of CAMS (CAMS 2007) occurred right at the time the stock market reached its highest point. Stocks were sharply falling during HRS 2008, so that stock wealth varied significantly within that wave depending on the interview date. Thus, because of the volatility of house and stock prices over the observation period, measured wealth in HRS differs from actual wealth at the time spending was undertaken and measured in CAMS; that is, there is a temporal misalignment of our spending and wealth measures (an issue we will deal with in our analysis). 
National indicators, such as those in Figure 1, mask the considerable amount of regional variation in the housing market over the course of the recession. This is very well documented by Figure 2. On the left, the figure shows the variation in the All-Transactions House Price Index of the Federal Housing Finance Agency (FHFA) for four states. In California, house prices doubled between the first quarter of calendar year 2002 (2002q1) and 2007q1 and almost halved between 2007q1 and 2011q4. In New York and Ohio, house prices increased by roughly $50 \%$ and $10 \%$, respectively, before the onset of the Great Recession and hardly decreased thereafter. In Michigan, house prices were on a downward trend before the crisis and continued to fall during the recessionary and post-recessionary periods. On the right, Figure 2 shows the variation in self-reported house values from the HRS. We use self-reported house values as our measure of housing wealth, and the figure demonstrates that changes in self-reported house values track actual house price changes quite closely. Consistent with the patterns in Figure 2, our empirical strategy of estimating the effect of shocks to housing wealth on spending is to use statelevel differences in house price change as instrumental variables for changes in housing wealth, assuming that house price changes during the Great Recession were unanticipated.

Table 1 shows spending and spending change over the decade 2002-2012 as derived from the measures in CAMS. ${ }^{8}$ We divide the decade into nonrecessionary and recessionary periods using the dating of business cycles by the National Bureau of Economic Research (NBER): 2007q4 marks the beginning and 2009q3 marks the end of the recession. We consider as "non-recessionary" spending changes those observed from 2003-2005, 2005-2007, and 2009-2011, and as "recessionary" changes those observed between 2007 and 2009. Our sample includes only those households observed in the two adjacent waves. We separately provide descriptive statistics for the entire sample (all respondents age 51-90), the sub-sample of those 65 or younger, and the sub-sample of those above age 65. In each two-year period, we further classify households

\footnotetext{
${ }^{8}$ Evidence of wealth changes over the decade 2002-2012 as derived from the measures in HRS is provided in Tables A1 and A2 in the Appendix.
} 


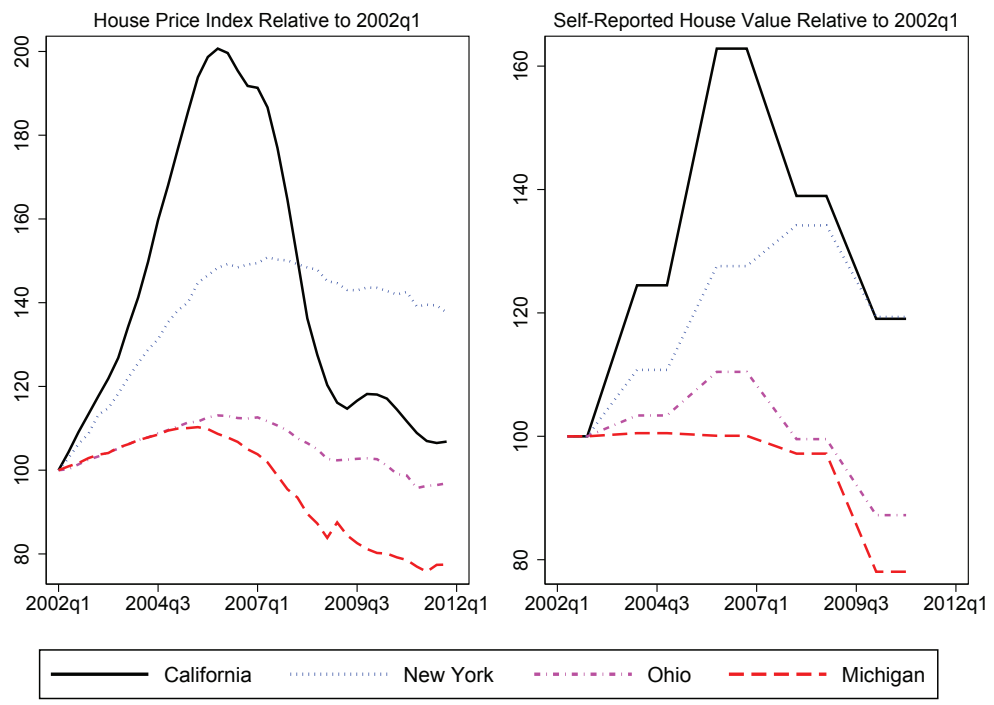

Figure 2: House Price Indices and House Values in Selected States

as "non-stock owners" (Non-SO) or "stock owners" (SO) according to whether the household held stocks at the beginning of the two-year period. The households in our sample reduced their spending by about $4.3 \%$ between the waves that we classify as non-recession times but they reduced spending by $7.8 \%$ between the recession waves $\left(2007\right.$ - 2009). ${ }^{9}$ That is, the average household experienced a 3.5-percentage-point excess decrease in spending during recessionary times (statistically significant at $1 \%$ ). The break down by age group reveals that, for those between 51 and 65 years of age, spending decreased by 5.5 percentage points more during the crisis than in non-crisis times (significant at 1\%), while it remained essentially the same for those older than 65. Differences-in-differences comparisons by stock ownership show that the average household holding stocks experienced an excess decrease in spending of 2.2 percentage points (but not statistically significant) compared to the average household with no stocks (last column, last line of first panel). However,

\footnotetext{
${ }^{9}$ In the Appendix we provide comparisons using average percentage changes in spending rather than percentage changes in average spending, which confirm the patterns described above. Household-level percentage changes in spending will be the outcome variable of interest in sections $4-6$.
} 
within the 51-65 age group, the excess decrease in spending for stockowners was around 8 percentage points and statistically significant at the 5 -percent level, while there are no detectable differences within the 66-90 age group.

In Table 2 we compare spending of homeowners grouped by the terciles of house price decline during the Great Recession. To define the terciles, we calculate, state by state, the percentage decline in house prices as measured by the FHFA index during the Great Recession (from 2007q4 to 2009q3) and assign each household to one of three groups corresponding to the terciles of the distribution of state-level price declines. Households residing in states that experienced large house price drops during the Great Recession (3rd tercile) report larger (negative) changes in their level of spending. For example, households in the states in the 3rd tercile reduced spending by $12 \%$ during the recession compared to an average reduction of about $4 \%$ between waves in non-recession times. More generally, homeowners in states with large (3rd tercile) and moderate (2nd tercile) house price declines exhibit a substantial and mostly statistically significant excess decrease in spending compared to their counterparts residing in states with small (1st tercile) house price declines. The observed excess decrease ranges from 5 to 8 percentage points in the whole sample, from 2 to 12 percentage points in the 51-65 age group and from 5 to 8 percentage points in the 66-90 age group.

\section{Differences-in-Differences Regression Results}

The empirical evidence we have presented so far is potentially confounded with differences in income and wealth (and more generally in socio-economic status) between asset owners and non-asset owners and across households residing in different states. To account for these sources of possible bias, we estimate a more comprehensive differences-in-differences regression model of this type:

$$
\Delta \log \left(C_{i t+1}\right)=\mathbf{x}_{i t}^{\prime} \alpha+\beta_{0} D_{r}+\beta_{1} O w n_{i t}+\beta_{2} D_{r} \times O w n_{i t}+v_{i t+1},
$$


Table 1: Mean Spending: All and by Stock Ownership

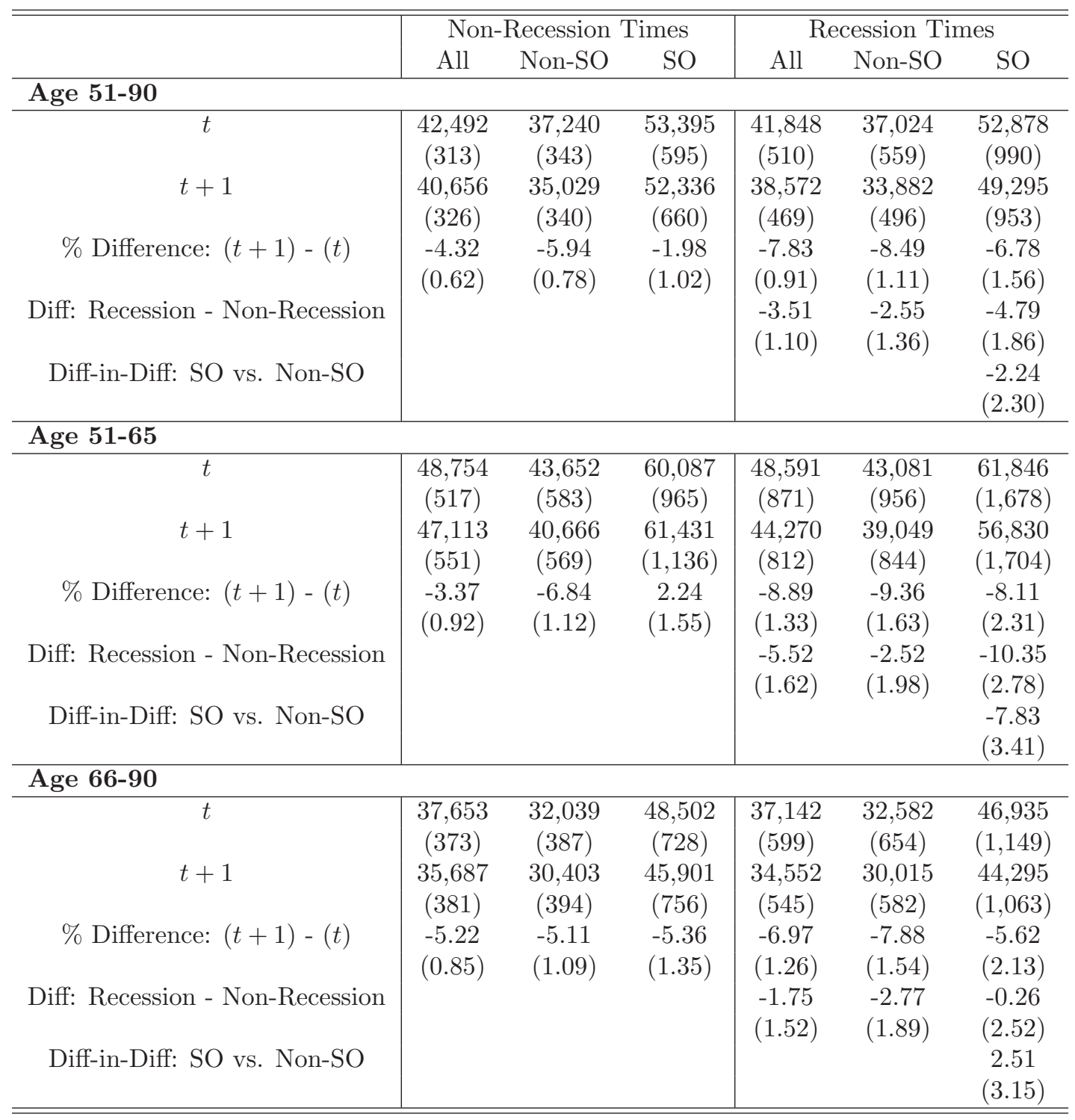

SO: Stockowners; Non-SO: Non-Stockowners. Delta Method standard errors in parentheses. Values are in 2011 dollars. In each survey wave we drop households with spending values in the top $1 \%$ or bottom $1 \%$ of the sample. For non-recession times, $t=2003 ; 2005 ; 2009$ and $t+1=2005 ; 2007 ; 2011$. For recession times $t=2007$ and $t+1=2009$. The computations only include households observed in both time $t$ and $t+1$. Amounts are in 2011 dollars. 
Table 2: Mean Spending by Terciles of House Price Decline during the Great Recession

\begin{tabular}{|c|c|c|c|c|c|c|}
\hline & \multicolumn{3}{|c|}{ Non-Recession Times } & \multicolumn{3}{|c|}{ Recession Times } \\
\hline & $1^{s t}$ Ter & $2^{\text {nd }}$ Ter & $3^{\text {rd }}$ Ter & $1^{\text {st }} \mathrm{Ter}$ & $2^{\text {nd }}$ Ter & $3^{\text {rd }}$ Ter \\
\hline \multicolumn{7}{|l|}{ Age 51-90 } \\
\hline$t$ & $\begin{array}{c}44,724 \\
(600)\end{array}$ & $\begin{array}{c}45,808 \\
(622)\end{array}$ & $\begin{array}{c}46,794 \\
(609)\end{array}$ & $\begin{array}{c}42,196 \\
(934)\end{array}$ & $\begin{array}{l}47,283 \\
(1,116)\end{array}$ & $\begin{array}{c}46,034 \\
(954)\end{array}$ \\
\hline$t+1$ & $\begin{array}{c}42,373 \\
(624)\end{array}$ & $\begin{array}{c}44,361 \\
(646)\end{array}$ & $\begin{array}{c}44,876 \\
(643)\end{array}$ & $\begin{array}{c}40,077 \\
(858)\end{array}$ & $\begin{array}{l}43,719 \\
(1,037)\end{array}$ & $\begin{array}{c}40,488 \\
(879)\end{array}$ \\
\hline$\%$ Difference: $(t+1)-(t)$ & $\begin{array}{l}-5.26 \\
(1.18)\end{array}$ & $\begin{array}{l}-3.16 \\
(1.14)\end{array}$ & $\begin{array}{l}-4.10 \\
(1.17)\end{array}$ & $\begin{array}{l}-5.02 \\
(1.67)\end{array}$ & $\begin{array}{l}-7.54 \\
(1.82)\end{array}$ & $\begin{array}{l}-12.05 \\
(1.55)\end{array}$ \\
\hline Diff: Recession - Non-Recession & & & & $\begin{array}{c}0.24 \\
(2.05)\end{array}$ & $\begin{array}{l}-4.38 \\
(2.15)\end{array}$ & $\begin{array}{l}-7.95 \\
(1.94)\end{array}$ \\
\hline Diff-in-Diff: $2^{\text {nd }}$ and $3^{r d}$ vs. $1^{\text {st }}$ & & & & & $\begin{array}{l}-4.62 \\
(2.96)\end{array}$ & $\begin{array}{l}-8.19 \\
(2.82)\end{array}$ \\
\hline Diff-in-Diff: $3^{r d}$ vs. $2^{\text {nd }}$ & & & & & & $\begin{array}{l}-3.57 \\
(2.89)\end{array}$ \\
\hline \multicolumn{7}{|l|}{ Age 51-65 } \\
\hline$t$ & $\begin{array}{c}51,114 \\
(938)\end{array}$ & $\begin{array}{l}51,980 \\
(1,000)\end{array}$ & $\begin{array}{l}53,871 \\
(1,022)\end{array}$ & $\begin{array}{l}48,113 \\
(1,489)\end{array}$ & $\begin{array}{l}54,523 \\
(1,880)\end{array}$ & $\begin{array}{l}55,435 \\
(1,648)\end{array}$ \\
\hline$t+1$ & $\begin{array}{c}48,877 \\
(980)\end{array}$ & $\begin{array}{l}50,608 \\
(1,043)\end{array}$ & $\begin{array}{l}52,508 \\
(1,126)\end{array}$ & $\begin{array}{l}45,195 \\
(1,419)\end{array}$ & $\begin{array}{l}51,088 \\
(1,778)\end{array}$ & $\begin{array}{l}46,595 \\
(1,564)\end{array}$ \\
\hline$\%$ Difference: $(t+1)-(t)$ & $\begin{array}{l}-4.38 \\
(1.69)\end{array}$ & $\begin{array}{l}-2.64 \\
(1.66)\end{array}$ & $\begin{array}{l}-2.53 \\
(1.75)\end{array}$ & $\begin{array}{l}-6.06 \\
(2.49)\end{array}$ & $\begin{array}{l}-6.30 \\
(2.69)\end{array}$ & $\begin{array}{r}-15.95 \\
(2.25)\end{array}$ \\
\hline Diff: Recession - Non-Recession & & & & $\begin{array}{l}-1.69 \\
(3.00)\end{array}$ & $\begin{array}{l}-3.66 \\
(3.16)\end{array}$ & $\begin{array}{r}-13.42 \\
(2.86)\end{array}$ \\
\hline Diff-in-Diff: $2^{\text {nd }}$ and $3^{r d}$ vs. $1^{\text {st }}$ & & & & & $\begin{array}{l}-1.97 \\
(4.36)\end{array}$ & $\begin{array}{c}-11.73 \\
(4.14)\end{array}$ \\
\hline Diff-in-Diff: $3^{r d}$ vs. $2^{\text {nd }}$ & & & & & & $\begin{array}{c}-9.76 \\
(4.26)\end{array}$ \\
\hline \multicolumn{7}{|l|}{ Age 66-90 } \\
\hline$t$ & $\begin{array}{c}38,982 \\
(736)\end{array}$ & $\begin{array}{c}40,610 \\
(749)\end{array}$ & $\begin{array}{c}41,815 \\
(725)\end{array}$ & $\begin{array}{c}37,418 \\
(1,142)\end{array}$ & $\begin{array}{l}42,125 \\
(1,340)\end{array}$ & $\begin{array}{c}39,857 \\
(1,069)\end{array}$ \\
\hline$t+1$ & $\begin{array}{c}36,558 \\
(761)\end{array}$ & $\begin{array}{c}39,211 \\
(786)\end{array}$ & $\begin{array}{c}39,568 \\
(732)\end{array}$ & $\begin{array}{l}35,998 \\
(1,024)\end{array}$ & $\begin{array}{c}38,481 \\
(1,215)\end{array}$ & $\begin{array}{c}36,487 \\
(991)\end{array}$ \\
\hline$\%$ Difference: $(t+1)-(t)$ & $\begin{array}{c}-6.22 \\
(1.64)\end{array}$ & $\begin{array}{c}-3.44 \\
(1.60)\end{array}$ & $\begin{array}{l}-5.37 \\
(1.59)\end{array}$ & $\begin{array}{l}-3.79 \\
(2.26)\end{array}$ & $\begin{array}{l}-8.65 \\
(2.52)\end{array}$ & $\begin{array}{l}-8.46 \\
(2.14)\end{array}$ \\
\hline Diff: Recession - Non-Recession & & & & $\begin{array}{c}2.42 \\
(2.79)\end{array}$ & $\begin{array}{l}-5.20 \\
(2.99)\end{array}$ & $\begin{array}{l}-3.08 \\
(2.66)\end{array}$ \\
\hline Diff-in-Diff: $2^{\text {nd }}$ and $3^{\text {rd }}$ vs. $1^{\text {st }}$ & & & & & $\begin{array}{l}-7.63 \\
(4.09)\end{array}$ & $\begin{array}{l}-5.50 \\
(3.86)\end{array}$ \\
\hline Diff-in-Diff: $3^{\text {rd }}$ vs. $2^{\text {nd }}$ & & & & & & $\begin{array}{c}2.12 \\
(4.00)\end{array}$ \\
\hline
\end{tabular}

Terciles are defined at the state level: the first and third terciles comprise the 17 states with the smallest and largest house price decline from $2007 \mathrm{q} 4$ to $2009 \mathrm{q} 2$, respectively. Other details as in Table 1 . 
where the dependent variable is the percent change in household $i$ spending between times $t$ and $t+1, D_{r}$ is an indicator for recession times, $O w n_{i t}$ is an indicator for asset (home or stock) ownership at time $t$, and $\mathbf{x}_{i t}$ is a vector of household characteristics at time $t$. The latter includes a quadratic in age, categorical variables for different levels of education, marital status, household size, health status, indicators for household income and wealth quartiles, indicators for labor force status, ownership group-specific time trends, and state fixed effects. To reduce the influence of outliers when estimating equation (4), we trim in each wave households for which percentage changes in spending are in the top or bottom 1 percent of the sample. We focus on $\beta_{2}$, which shows the excess change in spending among owners during the recession.

Table 3: Changes in Spending: Home Ownership and Stock Ownership

\begin{tabular}{|c|c|c|c|c|c|c|}
\hline \multirow{2}{*}{ Home Ownership } & \multicolumn{2}{|c|}{ Age 51-90 } & \multicolumn{2}{|c|}{ Age 51-65 } & \multicolumn{2}{|c|}{ Age $66-90$} \\
\hline & & & & & & \\
\hline \multirow[t]{2}{*}{$D_{r}$} & $0.045^{*}$ & $0.046^{*}$ & 0.055 & 0.054 & 0.041 & 0.041 \\
\hline & $(0.027)$ & $(0.028)$ & $(0.045)$ & $(0.045)$ & $(0.034)$ & $(0.034)$ \\
\hline \multirow[t]{2}{*}{ Home Ownership } & -0.014 & -0.014 & $-0.074^{*}$ & $-0.074^{*}$ & 0.026 & 0.026 \\
\hline & $(0.026)$ & $(0.027)$ & $(0.043)$ & $(0.044)$ & $(0.034)$ & $(0.035)$ \\
\hline \multirow[t]{2}{*}{$D_{r} \times$ Home Ownership } & $-0.075^{* *}$ & $-0.075^{* *}$ & $-0.118^{* *}$ & $-0.117^{* *}$ & -0.048 & -0.048 \\
\hline & $(0.030)$ & $(0.030)$ & $(0.049)$ & $(0.049)$ & $(0.038)$ & $(0.038)$ \\
\hline State Fixed Effects & No & Yes & No & Yes & No & Yes \\
\hline 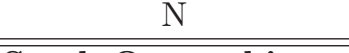 & 11158 & 11158 & 4824 & 4824 & 6334 & 6334 \\
\hline \multicolumn{7}{|l|}{ Stock Ownership } \\
\hline \multirow[t]{2}{*}{$D_{r}$} & -0.001 & -0.001 & -0.014 & -0.014 & 0.007 & 0.007 \\
\hline & $(0.014)$ & $(0.014)$ & $(0.021)$ & $(0.021)$ & $(0.018)$ & $(0.018)$ \\
\hline \multirow[t]{2}{*}{ Stock Ownership } & $0.050^{* *}$ & $0.049^{* *}$ & $0.067^{* *}$ & $0.067^{* *}$ & 0.026 & 0.025 \\
\hline & $(0.022)$ & $(0.022)$ & $(0.034)$ & $(0.034)$ & $(0.030)$ & $(0.031)$ \\
\hline \multirow[t]{2}{*}{$D_{r} \times$ Stock Ownership } & $-0.041^{*}$ & $-0.042^{*}$ & $-0.092^{* *}$ & $-0.093^{* *}$ & -0.008 & -0.009 \\
\hline & $(0.023)$ & $(0.023)$ & $(0.036)$ & $(0.036)$ & $(0.030)$ & $(0.030)$ \\
\hline State Fixed Effects & No & Yes & No & Yes & No & Yes \\
\hline $\mathrm{N}$ & 11194 & 11194 & 4843 & 4843 & 6351 & 6351 \\
\hline
\end{tabular}

Standard errors are clustered at the household level and reported in parentheses. ***, ** and $*$ indicate significance at the $1 \%, 5 \%$ and $10 \%$ level, respectively. In each survey wave we drop households with changes in spending in the top $1 \%$ or bottom $1 \%$ of the sample. Other controls are a quadratic in age, education dummies, marital status, household size, health status, indicators for household income and wealth quartiles, indicators for labor force status and ownership group-specific time trends.

The results in Table 3 confirm the empirical evidence revealed by simple 
comparisons of means across time and ownership groups. Specifically, compared to non-homeowners, the excess decrease in spending during the recession experienced by homeowners amounts to 7.5 percentage points, in the whole sample; to about 12 percentage points, in the 51-65 sub-sample; and to 5 percentage points (but not statistically significant), in the 66-90 sub-sample. Differences-in-differences estimates indicate that in the entire sample, the decrease in spending associated with the crisis is 4 percentage points larger for stockholders than for non-stockholders; in the group aged 51-65, the spending decrease is about 9 percentage points larger for stockholders; and in the group aged 66-90, the difference is not statistically different from zero. These conclusions are robust to the inclusion of ownership group-specific time trends as well as to the inclusion of state fixed effects. ${ }^{10}$

We also estimate a differences-in-differences regression for homeowners across states classified by the extent of house price decline during the Great Recession. We compare the spending change of households residing in states with larger house price drops (2nd and 3rd terciles) to that of households in states characterized by small house price drops during the crisis. The results are reported in Table 4. They confirm that the housing market shock significantly affected household spending and that spending reductions were largest among households who experienced the largest losses in house values. More precisely, homeowners in the states with the largest house price declines reduced their spending by 10 percentage points more during the recession than those in the states with the smallest house price declines. The excess decrease in spending with respect to homeowners in the 2nd tercile amounts to 5 percentage points (statistically significant at the 10-percent level). The estimates in Table 4 also confirm marked differences between the two age groups. The Great Recession had more severe consequences for younger households, which in tercile 3 reduced spending by about 4 percentage points more than the older households, relative to their counterparts in tercile 1.

\footnotetext{
${ }^{10}$ In the Appendix we document that the conclusions remain unchanged when, in order to minimize potential bias stemming from changes in ownership group composition before and after the recession, we restrict the estimation sample to households that did not change ownership status between 2006 and 2010.
} 
Table 4: Changes in Spending: Terciles of House Price Decline

\begin{tabular}{c|c|c|c}
\hline \hline & Age 51-90 & Age 51-65 & Age 66-90 \\
\hline$D_{r}$ & 0.024 & -0.005 & 0.047 \\
& $(0.022)$ & $(0.032)$ & $(0.029)$ \\
States $2^{\text {nd }}$ Ter & $0.053^{* *}$ & 0.005 & $0.093^{* *}$ \\
& $(0.027)$ & $(0.040)$ & $(0.038)$ \\
States $3^{\text {rd }}$ Ter & 0.014 & -0.035 & 0.054 \\
& $(0.027)$ & $(0.040)$ & $(0.037)$ \\
$D_{r} \times$ States $2^{\text {nd }}$ Ter & -0.051 & -0.036 & $-0.068^{*}$ \\
& $(0.031)$ & $(0.048)$ & $(0.041)$ \\
$D_{r} \times$ States $3^{r d}$ Ter & $-0.104^{* *}$ & $-0.138^{* *}$ & $-0.089^{* *}$ \\
& $(0.030)$ & $(0.045)$ & $(0.039)$ \\
\hline$D_{r} \times$ States $2^{r d}$ Ter $=$ & $\mathrm{F}=3.00$ & $\mathrm{~F}=4.64$ & $\mathrm{~F}=0.28$ \\
$D_{r} \times$ States $3^{r d}$ Ter & $\mathrm{p}$-val=0.08 & $\mathrm{p}$-val=0.03 & $\mathrm{p}$-val=0.60 \\
\hline $\mathrm{N}$ & 9122 & 4016 & 5106 \\
\hline \hline
\end{tabular}

Terciles are defined at the state level: the first and third terciles comprise the 17 states with the smallest and largest house price declines from 2007q4 to 2009q2, respectively. Standard errors are clustered at the household level and reported in parentheses. ***, ** and * indicate significance at the 1\%,5\% and $10 \%$ level, respectively. Other details as in Table 3.

These results are robust to the inclusion of state group-specific time trends and state fixed effects. They are also robust to the inclusion of state- and time-specific unemployment rates among the set of controls and to the exclusion of households affected by unemployment spells between 2006 and $2010 .^{11}$ Since across-state mobility is extremely limited in our sample, we do not expect the composition of state groups before and after the Great Recession to vary as the result of households' changing state of residence because of the crisis. ${ }^{12}$ To check whether our differences-in-differences estimates are confounded with other differences across states besides those induced by the Great Recession on local housing markets, we repeat the exercise in Table 4 using non-homeowners. The results of these "placebo" regressions are reported in Table A6 in the Appendix and reveal no differences in household mean spending across non-homeowners in different states before and after the crisis. Since

\footnotetext{
${ }^{11}$ The results using only households that did not experience unemployment between 2006 and 2010 are reported in Tables A7 and A8 in the Appendix.

${ }^{12}$ In Table A9 in the Appendix, we exclude from the regression sample those households that changed state of residence between 2006 and 2010. The results are unaffected both qualitatively and quantitatively.
} 
non-homeowners should be less concerned with the evolution of house prices than homeowners, but are equally affected by other state-level macroeconomic factors, we interpret this finding as evidence in support of the interpretation that the results in Table 4 are driven by differences in local housing market conditions during recessionary periods.

\section{The Elasticity of Household Spending to Housing Wealth Shocks}

We have documented reductions in household spending stemming from the differential impact of the Great Recession across groups residing in different areas and having different asset ownership status. In this section, we aim to quantify the response of household spending to the magnitude of the wealth shocks. For this purpose, we rely on the theoretical model sketched out in section 2 and exploit the large variation in household wealth brought about by the Great Recession to empirically test its predictions and identify the elasticity of consumption to wealth changes. More precisely, we bring equation (3) to the data and estimate:

$$
\Delta \log \left(C_{i t+1}\right)=\Delta Z_{i t+1}^{\prime} \lambda+\theta D_{r}+\epsilon_{n r} \Delta \log \left(W_{i t+1}\right)+\epsilon_{r} D_{r} \Delta \log \left(W_{i t+1}\right)+u_{i t+1} .
$$

In this regression model, the dependent variable, $\Delta \log \left(C_{i t+1}\right)$, is the change in $\log$ household $i$ spending across two consecutive waves. We want to assess how the change in household spending is related to in log household wealth, $\Delta \log \left(W_{i t+1}\right)$, after controlling for changes in demographic variables and for seasonal factors, $\Delta Z_{i t+1}^{\prime}$. To this end, we interact $\Delta \log \left(W_{i t+1}\right)$ with a binary variable, $D_{r}$, taking value 1 if $t$ and $t+1$ indicate a recessionary interval, and value 0 otherwise. As before, we assign to the recessionary interval those consumption changes observed between CAMS 2007 and CAMS 2009. Since household consumption information reported in each CAMS wave is linked to demographic and wealth measures collected in the preceding HRS wave, we assign to the recessionary interval the demographic and wealth changes observed between HRS 2006 and HRS 2008. The parameters $\epsilon_{n r}$ and $\epsilon_{r}$ in 
equation (5) represent the elasticities of household spending to wealth changes during non-recessionary and recessionary periods, respectively. The associated marginal propensities to consume out of wealth shocks can be computed by multiplying the elasticities by the ratio of household spending to household wealth. That is:

$$
M P C_{l}=\epsilon_{l} \frac{\overline{C_{l}}}{\overline{W_{l}}}, \quad l \in\{n r, r\},
$$

where $\overline{C_{l}}$ and $\overline{W_{l}}$ are sample averages. The term $u_{i t+1}$ in equation (5) is assumed to be an i.i.d. disturbance. Because we examine changes in spending over time, household fixed effects for levels of spending are differenced out.

Our hypothesis is that during the Great Recession the large wealth losses were unanticipated, so these shocks should have induced revisions in household consumption plans (e.g., $\epsilon_{r} \neq 0$ ). We hypothesize that before and after the crisis, expectations were for "normal" rates of return and that realized wealth changes were roughly as anticipated, prompting little or no adjustment in spending (e.g., $\epsilon_{n r}=0$ ). To test these implications, we estimate equation (5) using observed changes in household housing wealth brought about by the Great Recession. According to a standard life-cycle model like the one described in section 1, the elasticity of consumption with respect to an unanticipated and permanent shock to lifetime wealth should be equal to 1 , as long as there are no constraints preventing full adjustment. However, there are several reasons to expect the estimate of $\epsilon_{r}$ to be much smaller in this application. First, lifetime wealth not only includes the value of real estate, but also the value of financial assets, the present discounted value of the stream of future labor income and Social Security benefits, as well as the value of definedbenefit and defined-contribution pension plans or IRAs. In our specification, we abstract from the latter components and focus on wealth as measured by the value of housing assets. Clearly, an unexpected drop in the value of housing assets should induce a reduction in just the fraction of consumption that is anticipated to be financed out of this form of wealth. In all likelihood, this is substantially smaller than 1 . Second, since assets are not completely fungible due to their differing risk and return characteristics, households may 
prefer to own some assets over others for saving purposes, bequest motives, liquidity, tax or other reasons. Therefore, the effect of wealth changes on consumption is plausibly asset-type specific. This motivates the estimation of equation (5) for housing wealth only. The corresponding consumption elasticity is proportional to the ratio of housing wealth $\left(H W_{i t}\right)$ to total asset value, $W_{i t}=H W_{i t}+$ Other Wealth it $_{\text {. That is: }}$

$$
\frac{d \log C}{d \log H W}=\frac{d \log C}{d \log W} \times \frac{d \log W}{d \log H W}=\frac{d \log C}{d \log W} \times \frac{H W}{W} .
$$

Hence, it is likely to be less than 1 even if the elasticity of consumption with respect to total asset value is 1 . Third, the elasticity of total consumption to wealth may be weakened by the fact that some spending components may respond only over a long time horizon to changes in wealth.

We estimate equation (5) by instrumental variables (IV). Changes in household wealth observed over time not only reflect variations in asset prices, but are also the result of active saving and investment decisions. Such decisions, in turn, may have been made in response to specific household circumstances in both crisis and non-crisis periods. In order to isolate wealth shocks attributable to the Great Recession from changes due to active individual financial decisions, we instrument changes in housing wealth with changes in house prices at the state level. These are computed using state-specific house price indices published by the Federal Housing Finance Agency. ${ }^{13}$ Thus, it is the variation across states in house price changes during the decade 2002-2012 that identifies the effect of housing wealth shocks on spending. An additional reason for using IV estimation is measurement error in the change in house value caused by observation error (survey noise), and by the temporal incoherence between the HRS measure of housing wealth and the CAMS measure of spending.

In our baseline specification, the set of controls, $\Delta Z_{i t+1}$, includes age and education of the survey respondent, change in marital status, change in household size, and change in health status of the survey respondent across two

\footnotetext{
${ }^{13}$ The data can be downloaded from http://www.fhfa.gov/DataTools/Downloads/Pages/HousePrice-Index-Datasets.aspx\#qat.
} 
consecutive waves. ${ }^{14}$ To guard against spending changes being driven by unemployment shocks, we add to the baseline specification changes in total household income, in work status, and in the state-level unemployment rate across two consecutive waves. Next, we add to the set of explanatory variables the change in household wealth other than housing wealth. All regression models are estimated with and without state fixed effects. ${ }^{15}$

In Table 5, we report the results of the estimation of equation (5). The sample comprises households that own their homes and whose survey respondent is between 51 and 90 years of age. To reduce the influence of outliers, we trim in each survey wave households that report percentage changes in spending or percentage changes in house value in the top or bottom 1 percent of the sample. We use changes in house prices at the state level (in non-recessionary and recessionary times) as instruments for changes in housing wealth (in nonrecessionary and recessionary times). The first-stage regression results (reported in Table A10 in the Appendix) show a strong correlation between the instruments and the endogenous regressors. The null hypotheses that the model is under- and weakly identified are both rejected at any sensible level of significance $\left(\chi_{1}^{2}=82.5\right.$ and $F_{2,3105}=44.6$, respectively). Reduced-form regressions (Table A11 in the Appendix) document a significant association between changes in household spending and changes in house prices during the recession period, as well as the absence of such an association during non-recessionary times. Our exclusion restriction is that, conditional on changes in household demographics, working status, and state-level employment conditions, changes in house prices brought about by the Great Recession should impact spending decisions of homeowners only through changes in house values.

The estimates in Table 5 are qualitatively consistent with theoretical pre-

\footnotetext{
${ }^{14}$ We assume that the set of demographics, $Z_{i t}$, shifting the utility function in equation (1) includes a quadratic in age, education group indicators, marital status, household size, and health status. After taking differences across two consecutive waves, $\Delta Z_{i t}$ in equation (3) reduces to the one described in the text. Even though education is constant over time for all respondents in the sample, we retain indicators for education levels in equation (5) because the change in consumption may be related to them.

${ }^{15}$ Since households move across states (even though only a minority do so), state fixed effects are not differenced out in equation (5).
} 
Table 5: Housing Wealth Elasticity and MPC

\begin{tabular}{|c|c|c|c|c|c|c|}
\hline & (I) & (II) & (III) & (IV) & $(\mathrm{V})$ & (VI) \\
\hline$\epsilon_{n r}$ & $\begin{array}{c}-0.038 \\
(0.041)\end{array}$ & $\begin{array}{c}-0.036 \\
(0.043)\end{array}$ & $\begin{array}{c}-0.038 \\
(0.071)\end{array}$ & $\begin{array}{c}-0.034 \\
(0.078)\end{array}$ & $\begin{array}{l}-0.038 \\
(0.071)\end{array}$ & $\begin{array}{c}-0.033 \\
(0.078)\end{array}$ \\
\hline$\epsilon_{r}$ & $\begin{array}{c}0.420^{* * *} \\
(0.159)\end{array}$ & $\begin{array}{c}0.419^{* *} \\
(0.207)\end{array}$ & $\begin{array}{c}0.414^{* * *} \\
(0.158)\end{array}$ & $\begin{array}{c}0.412^{* *} \\
(0.207)\end{array}$ & $\begin{array}{c}0.407^{* * * *} \\
(0.158)\end{array}$ & $\begin{array}{c}0.405^{* *} \\
(0.206)\end{array}$ \\
\hline \multirow[t]{2}{*}{$D_{r}$} & 0.008 & 0.008 & 0.007 & 0.008 & 0.007 & 0.007 \\
\hline & (0.017) & $\begin{array}{l}0.020) \\
(0.020)\end{array}$ & (0.017) & $\begin{array}{l}(0.020) \\
0\end{array}$ & $\begin{array}{l}(0.017) \\
-0000\end{array}$ & $\begin{array}{l}(0.020) \\
0\end{array}$ \\
\hline \multirow{2}{*}{ Age } & -0.000 & -0.000 & -0.000 & -0.000 & -0.000 & -0.000 \\
\hline & $(0.000)$ & $(0.000)$ & $(0.000)$ & $(0.001)$ & $(0.000)$ & $(0.001)$ \\
\hline \multirow[t]{2}{*}{ High School } & 0.013 & 0.008 & 0.013 & 0.008 & 0.013 & 0.007 \\
\hline & $(0.011)$ & $(0.011)$ & $(0.011)$ & $(0.011)$ & $(0.011)$ & $(0.011)$ \\
\hline \multirow[t]{2}{*}{ Some College } & $0.024^{* *}$ & $0.021^{*}$ & $0.023^{* *}$ & $0.021^{*}$ & $0.023^{* *}$ & $0.020^{*}$ \\
\hline & $(0.011)$ & $(0.011)$ & $(0.011)$ & $(0.012)$ & $(0.011)$ & $(0.012)$ \\
\hline \multirow[t]{2}{*}{ College or More } & $0.019^{*}$ & 0.017 & 0.018 & 0.016 & 0.017 & 0.016 \\
\hline & $(0.011)$ & $(0.011)$ & $(0.011)$ & $(0.011)$ & $(0.011)$ & $(0.011)$ \\
\hline \multirow[t]{2}{*}{$\Delta$ Household Size } & 0.008 & 0.008 & 0.008 & 0.008 & 0.008 & 0.008 \\
\hline & $(0.009)$ & $(0.009)$ & $(0.009)$ & $(0.009)$ & $(0.009)$ & $(0.009)$ \\
\hline \multirow[t]{2}{*}{ Partnered $\rightarrow$ Single } & $-0.106^{* * *}$ & $-0.110^{* * *}$ & $-0.105^{* * *}$ & $-0.108^{* * *}$ & $-0.105 * * *$ & $-0.109 * * *$ \\
\hline & $(0.034)$ & $(0.034)$ & $(0.034)$ & $(0.034)$ & $(0.034)$ & $(0.034)$ \\
\hline \multirow[t]{2}{*}{ Single $\rightarrow$ Partnered } & $0.095^{*}$ & $0.094^{*}$ & $0.094^{*}$ & $0.093^{*}$ & $0.092^{*}$ & $0.090^{*}$ \\
\hline & $(0.050)$ & $(0.050)$ & $(0.050)$ & $(0.050)$ & $(0.050)$ & $(0.050)$ \\
\hline \multirow[t]{2}{*}{ Health Worsening } & -0.017 & -0.018 & -0.016 & -0.017 & -0.016 & -0.017 \\
\hline & $(0.012)$ & $(0.012)$ & $(0.012)$ & $(0.012)$ & $(0.012)$ & $(0.012)$ \\
\hline \multirow[t]{2}{*}{ Health Improvement } & -0.001 & -0.002 & -0.001 & -0.002 & -0.001 & -0.002 \\
\hline & $(0.013)$ & $(0.013)$ & $(0.013)$ & $(0.013)$ & $(0.013)$ & $(0.013)$ \\
\hline \multirow[t]{2}{*}{$\Delta($ Household Income $)$} & & & 0.002 & 0.002 & 0.002 & 0.002 \\
\hline & & & $(0.006)$ & $(0.006)$ & $(0.006)$ & $(0.006)$ \\
\hline \multirow[t]{2}{*}{ Work $\rightarrow$ Work } & & & 0.009 & 0.008 & 0.008 & 0.008 \\
\hline & & & $(0.009)$ & $(0.009)$ & $(0.009)$ & $(0.009)$ \\
\hline \multirow[t]{2}{*}{ NoWork $\rightarrow$ Work } & & & 0.008 & 0.011 & 0.008 & 0.011 \\
\hline & & & $(0.029)$ & $(0.029)$ & $(0.029)$ & $(0.029)$ \\
\hline \multirow[t]{2}{*}{ Work $\rightarrow$ No Work } & & & -0.025 & -0.026 & -0.026 & -0.027 \\
\hline & & & $(0.019)$ & $(0.019)$ & $(0.019)$ & $(0.019)$ \\
\hline \multirow[t]{2}{*}{$\Delta \log ($ State Un. Rate $)$} & & & 0.001 & 0.002 & 0.001 & 0.003 \\
\hline & & & $(0.027)$ & $(0.028)$ & $(0.027)$ & $(0.028)$ \\
\hline \multirow[t]{2}{*}{$\Delta($ Other Wealth $)$} & & & & & 0.003 & 0.003 \\
\hline & & & & & $(0.002)$ & $(0.002)$ \\
\hline \multirow[t]{2}{*}{ Constant } & -0.043 & -0.018 & -0.055 & -0.030 & -0.055 & -0.031 \\
\hline & $(0.031)$ & $(0.046)$ & $(0.037)$ & $(0.050)$ & $(0.037)$ & $(0.050)$ \\
\hline State Fixed Effects & No & Yes & No & Yes & No & Yes \\
\hline \multicolumn{7}{|c|}{ Marginal Propensity to Consume } \\
\hline \multirow[t]{2}{*}{$M P C_{n r}$} & -0.008 & -0.008 & -0.008 & -0.007 & -0.008 & -0.007 \\
\hline & $(0.010)$ & $(0.010)$ & $(0.016)$ & $(0.017)$ & $(0.016)$ & $(0.017)$ \\
\hline \multirow[t]{2}{*}{$M P C_{r}$} & $0.074^{* *}$ & $0.073^{* *}$ & $0.073^{* *}$ & $0.072^{* *}$ & $0.071^{* *}$ & $0.071^{* *}$ \\
\hline & $(0.029)$ & $(0.035)$ & $(0.029)$ & $(0.035)$ & $(0.029)$ & $(0.035)$ \\
\hline $\mathrm{N}$ & 8621 & 8621 & 8621 & 8621 & 8621 & 8621 \\
\hline
\end{tabular}

Standard errors are clustered at the household level and reported in parentheses. Standard errors for estimated marginal propensity to consume are computed by bootstrap using 500 replications. $* * * * *$ and $*$ indicate significance at the $1 \%, 5 \%$ and $10 \%$ level, respectively. Housing wealth is defined as the value of the primary residence at the time of the HRS interview. In each survey wave we drop households with changes in spending or housing wealth in the top $1 \%$ or bottom $1 \%$ of the sample. Household income and other wealth are transformed using the inverse hyperbolic sine transformation. 
dictions. The elasticity of household spending to changes in housing wealth is indistinguishable from zero in non-recessionary periods, but positive and statistically significant in recessionary periods. This indicates that homeowners revise their consumption plans in response to unanticipated changes in house values. The estimated elasticity is roughly 0.40 and stable across specifications. It implies a marginal propensity to consume (MPC) out of housing wealth between 0.071 and 0.074 . The only other significant coefficients are those of changes in marital status. Since the CAMS elicits consumption at the household level, changes in marital status are quite likely to have an effect on the observed level of spending. Respondents transitioning from partner-hood to single-hood across two consecutive waves report a drop in consumption of around 10 percentage points compared to those who remain partnered. Conversely, those who transition from being single to being partnered report their spending increases by 9 percentage points more across two consecutive waves. The estimates in Table 5 also reveal an education gradient. Albeit differences across education groups are modest, we observe that households with more education have smaller reductions in spending as they age (flatter consumption paths). This is consistent with a life-cycle model where higher mortality risk, associated with lower education, causes spending to be reduced more rapidly with age. Changes in household income, working status, and state-level employment conditions are not associated with revisions of household spending decisions in our sample. While this finding may seem surprising, it is worth mentioning that the Great Recession had a very modest impact on the working situation and income of the individuals in our sample: the average change in household income across two consecutive waves is roughly $-0.5 \%$ in both non-recessionary and recessionary periods. Also, roughly $8 \%$ of the sample transition from working to not working over the 2002-2012 decade. Among them, $80 \%$ retire and $13 \%$ become unemployed or move out of the labor force across two consecutive waves. ${ }^{16}$ Importantly, these percentages are virtually identical during non-recessionary and recessionary times. In the Appendix

\footnotetext{
${ }^{16}$ About $5 \%$ of those who transition from working to not-working report becoming disabled, while $2 \%$ report working part-time.
} 
(Table A12) we repeat the regression analyses after excluding households that experienced unemployment between 2006 and 2010 and obtain results very similar to those described in this section.

Our estimates of the marginal propensity to consume (MPC) out of housing wealth (between 0.071 and 0.074) are within the range found in previous studies. Using aggregate time series for U.S. states, Case et al. (2005, 2013) estimate an MPC out of housing wealth between 3 and 4 cents on the dollar. In contrast, they find no evidence that private consumption responds to changes in financial wealth. Carroll et al. (2011) estimate an "eventual" (medium-run) MPC out of housing wealth of $0.09 .{ }^{17}$ As far as evidence based on microeconomic data is concerned, studies of wealth effects have been limited by the lack of reliable household-level data on both consumption and wealth. Engelhardt (1996) uses a sample of homeowners under age 65 drawn from the 1984-1989 Panel Study of Income Dynamics. He defines savings as the difference between self-reported non-housing asset values between 1984 and 1989 and relates such measure to real housing capital gains over the same period. He estimates an MPC out of housing wealth of 0.14 for the average household and of 0.03 for the median household. He documents that the response of consumption to changes in home values is entirely driven by changes in the behavior of households experiencing capital losses, while those experiencing capital gains do not revise their spending plans. This is in line with our findings: we estimate sizeable and statistically significant housing wealth effects during the Great Recession, when home values decreased sharply in most areas, but according to our estimates there is no response of consumption to housing wealth during non-recessionary periods, when home values were either increasing prior to the crisis or recovering after the crisis. Campbell and Cocco (2007) use data from the UK Family Expenditure Survey (FES) over the period 1988-2000. Exploiting regional home price variation and an IV estimation strategy similar to ours, they find that homeowners above the age

\footnotetext{
${ }^{17}$ The authors refer to the "eventual" MPC as the one reflecting the medium-run dynamics of consumption that happen over the course of a few years. This measure is closer to the one we estimate than its short-run (next quarter) counterpart.
} 
of 40 exhibit an elasticity of consumption to housing wealth as large as 1.2 , implying an MPC of 0.11 ; renters 40 or younger do not respond to changes in local house prices. In contrast, Attanasio et al. (2009) use FES data from 1978 to 2002 and document a stronger relationship between house prices and consumption growth for younger households compared to older households. These seemingly contradictory conclusions likely arise from differences in the sample periods and in the relative importance of the mechanisms driving responses to housing wealth changes at different points in time. These studies face some data limitations. Because the FES is cross-sectional they rely on pseudo-panel estimation techniques, which prevent them from fully exploiting household heterogeneity. Their measure of consumption excludes purchases of large, infrequently purchased items and the FES does not elicit household asset values. Also the time span under study has booms and busts in house prices that were considerably smaller in magnitude (mostly 10\%) than the drop in home values brought about by the Great Recession and there was less heterogeneity across regions than the one observed in the US over the decade 2002-2012.

The life-cycle model that we outlined in section 1 provides a general explanation for our results under the assumption that the wealth changes in the Great Recession were unanticipated, but it does not provide a mechanism. One possible mechanism is that the primary residence is an asset that can be used as collateral in a loan. When prices are increasing a relatively high level of consumption can be sustained by the continued extraction of the increasing equity. Indeed, Mian and Sufi (2011) show that American homeowners significantly increased their borrowing in response to changes in their home equity over the decade 1997-2008 and used it to mainly finance real outlays, such as consumption or home improvements. In this scenario consumption would not be increasing even as housing wealth increased; it would be maintained at an elevated level. However, a positive association between changes in household spending and changes in housing wealth would result from borrowing constraints binding when home prices decreased, as was the case during the Great Recession. Households would have had to reduce consumption from its 
high level as the source of credit dried up. We find that in our sample over age 50 spending was more responsive to wealth change among relatively younger households than among older households. A possible explanation is a bequest motive. Often the bequest is in the form of a house, which means fluctuations in the value of a house simply translate into fluctuations in the value of a bequest, not in spending by the older household. More generally, if risk aversion is large so that the marginal utility of consumption has considerable variation as consumption varies, and the marginal utility of bequests is relatively constant, bequests will be the residual claimant of assets: variations in wealth will be absorbed by variations in bequests, not by variations in spending.
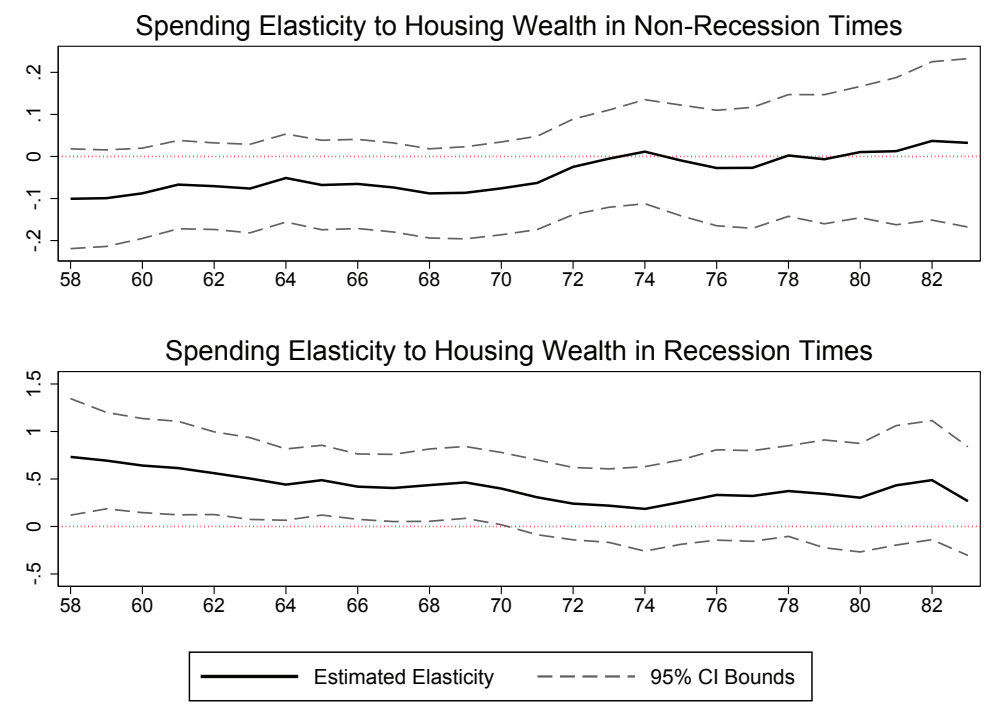

Figure 3: Housing Wealth Elasticity by Age Group

To assess the extent to which housing wealth effects vary with age, we reestimate our model for different sub-samples defined by a rolling 14-year age interval (e.g., 51-65, 52-66, , 76-90). Figure 3 shows the estimated elasticities for non-recessionary and recessionary periods, within their $95 \%$ confidence intervals. The elasticity of household spending to changes in housing wealth in non-recessionary times is indistinguishable from zero across all sub-samples. The response of household spending to changes in housing wealth in reces- 
sionary times ranges from 0.68 to 0.25 and exhibits a slightly decreasing age trend. Most importantly, it is statistically significant for relatively younger households and becomes statistically indistinguishable from zero for all subsamples age 64-78 and older. This result is consistent with the descriptive statistics of section 3, which showed that the declines in housing wealth and spending associated with the Great Recession were much sharper for households below the age of 65 than for their older counterparts. The findings in Figure 3 also lend support to the view that borrowing constraints were at least partly responsible for the decline in consumption. Households in their 70s and 80s have more financial assets than those in their 50s and 60s. To the extent that home equity was used to finance consumption prior to the recession, young owners would be less likely to be able to smooth consumption when equity loans dried up, whereas older households could smooth consumption by drawing on assets.

\section{The Elasticity of Household Spending to Financial Wealth Shocks}

To estimate the response of spending to changes in housing wealth, we relied on spatial variation in house price changes. This approach cannot be used for identifying the elasticity of household spending to financial wealth, as stock prices do not vary across states. Because of variation in HRS interview date within each wave of data collection, we do have cross-sectional variation in stock wealth stemming from individuals reporting the value of their financial assets in different stock market circumstances. For instance, during the 2008 wave of the HRS, individuals interviewed before October had not yet witnessed the nearly $25 \%$ drop in the Dow Jones Industrial Average, and reported the value of their financial wealth in a very different climate than did those interviewed after the October crash. However, the variation in wealth caused by differences in interview dates is not matched to the reporting period for spending, which is approximately the same for all respondents (Oc- 
tober/November of each CAMS interview year). For example, food spending in CAMS is mostly reported as "last week" which would refer to the last week in September. Thus, stock wealth variation across households induced by variation in interview dates is not relevant for understanding spending variation. A second problem is that because of the relatively quick stock market recovery in 2009, the difference in reported financial wealth between the 2008 and 2010 HRS waves does not adequately reflect the drop in stock market prices brought about by the Great Recession. Finally, the high variability and measurement error in self-reported values of financial assets make the association between changes in stock market prices and household financial wealth very weak. ${ }^{18}$

To overcome these issues, we adopt the following strategy, which we call a grouping strategy, to estimate the response of household spending to changes in financial wealth. First, we bring the HRS measure of financial wealth forward to the time of the CAMS interview, similar to the approach taken by Banks et al. (2013). That is, we adjust each households asset values observed in the HRS core wave by an estimate of the price change of the assets between the time of the HRS core interview and the subsequent wave of CAMS (e.g., financial wealth reported in the 2006 HRS wave is brought forward to the 4th quarter of 2007; financial wealth reported in the 2008 HRS wave is brought forward to the 4th quarter of 2009). We consider three broad categories, namely stocks, bonds, and the sum of all other financial assets (CDs, T-Bills, and checking and savings accounts). We take the value of these financial assets in a given HRS wave and multiply it by the corresponding realized price change from the time of the HRS interview to the time of the CAMS interview. Specifically, we use the change in the S\&P 500 index for stocks, the change in the Merrill Lynch U.S. Corp Master Total Return Index for bonds, and the change in the interest rate for CDs, T-Bills, and checking and savings accounts. This accomplishes the objectives of matching financial wealth to the reporting time period of spending and better capturing the exogenous wealth changes that individu-

\footnotetext{
${ }^{18}$ Studies of the effect of stock price change on outcomes measured in the HRS core interview do not have a similar mismatch. Hudomiet et al. (2011) and McInerney et al. (2013) rely on HRS interview date variation to identify the effect of the stock market crash of October 2008 on stock market return expectations and mental health, respectively.
} 
als may have experienced during the recession. Second, we rely on a grouping method to compute changes in financial wealth and spending for stockowners and non-stockowners in non-recessionary and recessionary periods. This allows us to greatly reduce the impact of measurement error on our parameters of interest. Specifically, we compute average log spending in two consecutive waves during non-recessionary times $\left(\overline{\log \left(C_{t}^{n r}\right)}\right.$ and $\overline{\log \left(C_{t+1}^{n r}\right)}$ ) and recessionary times $\left(\overline{\log \left(C_{t}^{r}\right)}\right.$ and $\left.\overline{\log \left(C_{t+1}^{r}\right)}\right)$ for non-stockowners and stockowners. Similarly, we compute average log financial wealth in two consecutive waves during non-recessionary times $\left(\overline{\log \left(F W_{t}^{n r}\right)}\right.$ and $\left.\overline{\log \left(F W_{t+1}^{n r}\right)}\right)$ and recessionary times $\left(\overline{\log \left(F W_{t}^{r}\right)}\right.$ and $\overline{\log \left(F W_{t+1}^{r}\right)}$ ) for non-stockowners and stockowners. Working with these quantities, we obtain differences-in-differences estimates of the effect of the recession for spending and financial wealth by comparing stockowners (SO) and non-stockowners (Non-SO), namely:

$$
\begin{gathered}
\Delta_{\text {spend }}=\left[\left(\overline{\left(\Delta \log \left(C_{t+1}^{r}\right)\right.}-\overline{\Delta \log \left(C_{t+1}^{n r}\right)}\right)^{S O}-\left(\overline{\Delta \log \left(C_{t+1}^{r}\right)}-\overline{\Delta \log \left(C_{t+1}^{n r}\right)}\right)^{N o n-S O}\right], \\
\Delta_{f w}=\left[\left(\overline{\Delta \log \left(F W_{t+1}^{r}\right)}-\overline{\Delta \log \left(F W_{t+1}^{n r}\right)}\right)^{S O}-\left(\overline{\Delta \log \left(F W_{t+1}^{r}\right)}-\overline{\Delta \log \left(F W_{t+1}^{n r}\right)}\right)^{N o n-S O}\right] .
\end{gathered}
$$

We assume that the differential impact on financial assets of the drop in stock market prices during the Great Recession can be used to recover the unexpected wealth loss by stock owners; that is, we interpret $\Delta_{f w}$ to be the unexpected wealth loss experienced by stock owners. Similarly, $\Delta_{\text {spend }}$ is the change in spending resulting from that loss. Based on these assumptions we calculate the elasticity and marginal propensity to consume out of financial wealth as

$$
\epsilon_{f w}=\frac{\Delta_{\text {spend }}}{\Delta_{f w}} \quad \text { and } \quad M P C_{f w}=\epsilon_{f w} \times \frac{\overline{F W}}{\bar{C}} .
$$

Standard errors for average log spending and average log financial wealth are computed by bootstrap (using 500 replications) with household-level clusters. We then apply the Delta Method to obtain the standard errors for the quantities in equations (8) and (9). The results of these calculations are reported in Table 6. 
We find that the elasticity of household spending to (unexpected) changes in financial wealth is 0.22 with a $p$-value of 0.052 . It implies a marginal propensity to consume out of financial wealth of about 4 cents on the dollar. This value is substantially smaller than the estimated MPC out of housing wealth and consistent with what has been found in other studies. Using aggregate

Table 6: Financial Wealth Elasticity and MPC

\begin{tabular}{|c|c|c|c|c|}
\hline \multirow{3}{*}{ Non Recession Times } & \multicolumn{2}{|c|}{ Non-SO } & \multicolumn{2}{|c|}{$\overline{\mathrm{SO}}$} \\
\hline & \multirow[t]{2}{*}{$\ln ($ Spending $)$} & \multirow[t]{2}{*}{$\ln ($ Fin.W $)$} & \multirow[t]{2}{*}{$\ln ($ Spending $)$} & \multirow[t]{2}{*}{$\ln (F i n . W)$} \\
\hline & & & & \\
\hline$t$ & $\begin{array}{c}10.31 \\
(0.012)\end{array}$ & $\begin{array}{c}8.98 \\
(0.045)\end{array}$ & $\begin{array}{c}10.76 \\
(0.015)\end{array}$ & $\begin{array}{c}11.63 \\
(0.038)\end{array}$ \\
\hline$t+1$ & $\begin{array}{c}10.23 \\
(0.013)\end{array}$ & $\begin{array}{c}9.05 \\
(0.046)\end{array}$ & $\begin{array}{c}10.71 \\
(0.015)\end{array}$ & $\begin{array}{l}11.46 \\
(0.041)\end{array}$ \\
\hline$\Delta_{t+1}^{n r}$ & $\begin{array}{l}-0.072 \\
(0.006)\end{array}$ & $\begin{array}{c}0.070 \\
(0.022)\end{array}$ & $\begin{array}{l}-0.051 \\
(0.008)\end{array}$ & $\begin{array}{l}-0.174 \\
(0.022)\end{array}$ \\
\hline \multicolumn{5}{|l|}{ Recession Times } \\
\hline$t$ & $\begin{array}{c}10.30 \\
(0.016)\end{array}$ & $\begin{array}{c}8.99 \\
(0.055)\end{array}$ & $\begin{array}{c}10.76 \\
(0.020)\end{array}$ & $\begin{array}{c}11.77 \\
(0.051)\end{array}$ \\
\hline$t+1$ & $\begin{array}{c}10.23 \\
(0.014)\end{array}$ & $\begin{array}{c}9.07 \\
(0.058)\end{array}$ & $\begin{array}{c}10.66 \\
(0.020)\end{array}$ & $\begin{array}{c}11.39 \\
(0.061)\end{array}$ \\
\hline$\Delta_{t+1}^{r}$ & $\begin{array}{l}-0.067 \\
(0.009)\end{array}$ & $\begin{array}{c}0.081 \\
(0.038)\end{array}$ & $\begin{array}{l}-0.094 \\
(0.014)\end{array}$ & $\begin{array}{l}-0.384 \\
(0.040)\end{array}$ \\
\hline $\begin{array}{c}\Delta_{t+1}^{r}-\Delta_{t+1}^{n r} \\
\Delta\left[\Delta_{t+1}^{r}-\Delta_{t+1}^{n r}\right]\end{array}$ & $\begin{array}{c}0.006 \\
(0.013)\end{array}$ & $\begin{array}{c}0.011 \\
(0.049)\end{array}$ & $\begin{array}{c}-0.044 \\
(0.018) \\
-0.049 \\
(0.022)\end{array}$ & $\begin{array}{c}-0.210 \\
(0.050) \\
-0.220 \\
(0.065)\end{array}$ \\
\hline$\epsilon=\frac{\Delta_{\text {spend }}\left[\Delta_{t+1}^{r}-\Delta_{t+1}^{n r}\right]}{\Delta_{f w}\left[\Delta_{t+1}^{r}-\Delta_{t+1}^{n r}\right]}$ & \multicolumn{4}{|c|}{$0.224 \nmid(0.115)$} \\
\hline$M P C=\epsilon \times \frac{\overline{f w}}{\overline{s p e n d}}$ & \multicolumn{4}{|c|}{$0.039 \dagger(0.020)$} \\
\hline
\end{tabular}

Standard errors are clustered at the household level and reported in parentheses. Standard errors for averages are computed by bootstrap using 500 replications. Standard errors for differences are computed by Delta Method. † indicates that the coefficient is significant at $10 \%$. In each survey wave we drop households with changes in spending or financial wealth in the top $1 \%$ or bottom $1 \%$ of the sample. For non-recession times, $t=2003 ; 2005 ; 2009$ and $t+1=2005 ; 2007 ; 2011$. For recession times $t=2007$ and $t+1=2009$. The computations only include households observed in both time $t$ and $t+1$.

data, Case et al. $(2005,2013)$ estimate an MPC out of financial wealth between 0.01 and 0.02 (not statistically different from zero). Carroll et al. (2011) 
find that the response of consumption to changes in the value of financial assets is around 0.04 , less than half the size of the response to changes in housing wealth. Microeconomic evidence on the relationship between household spending and the value of financial assets is more scarce. Sierminska and Takhtamanova (2007) and Bostic et al. (2009) find that consumption responds considerably less to financial than to housing wealth shocks. Christelis et al. (2015) estimate an MPC for financial wealth of 0.033, which is very close to the value reported in Table 6. On the other hand, their estimated MPC for housing wealth of 0.009 is substantially lower than the value we obtain in Table $5 .^{19}$

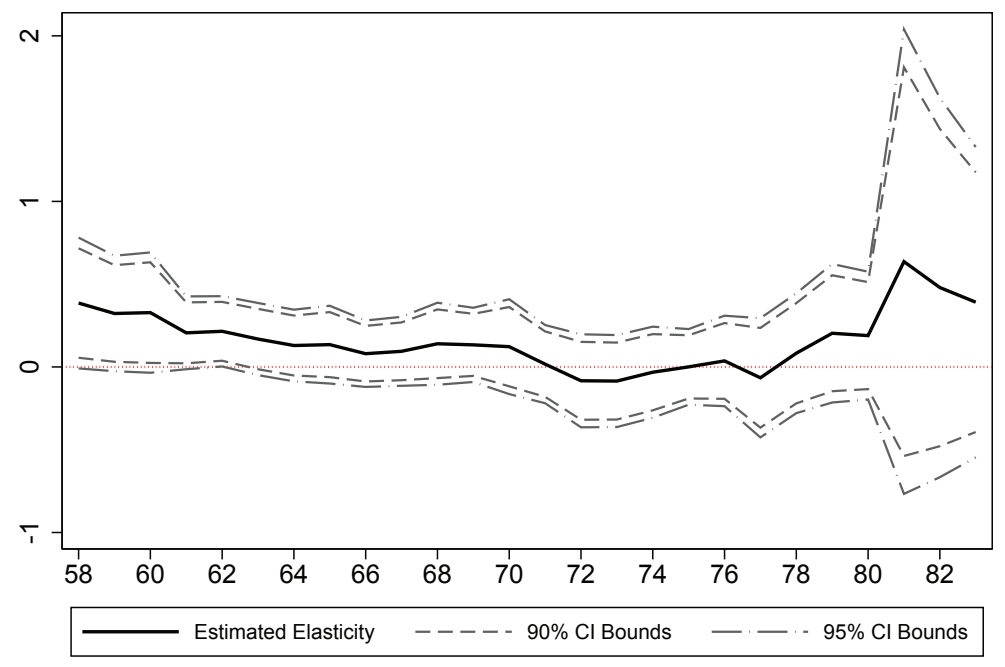

Figure 4: Financial Wealth Elasticity in Recession Times by Age Group

In Figure 4 we show the extent to which the financial wealth elasticity varies with age by estimating it for subsamples defined by rolling 14-year age intervals $(51-65,52-66$, , 76-90). Figure 4 reports the point estimates and their $95 \%$ and $90 \%$ confidence intervals using the grouping method described above. The elasticity of household spending to financial wealth shocks is 0.39

\footnotetext{
${ }^{19}$ Christelis et al. (2015) use self-reported changes in housing and stock wealth as elicited by the 2009 HRS Internet survey. Changes in housing wealth refer to the period between the second quarter of 2006 and the time of the interview. Changes in stock market wealth refer to the period between September 2008 and the time of the interview. Because of this, estimated MPCs out of financial and housing wealth are not directly comparable.
} 
in the youngest age band (51-65) shown as centered at age 58, and declines, reaching zero for the sample with age centered at 71 . This pattern is in line with the descriptive evidence presented in section 3 and with the regression results provided in section 4 , both of which point to larger spending responses to the financial turmoil among 51-65-year-olds.

\section{Conclusions}

Our identification strategy for the effect of house price changes on spending during the Great Recession was to use the substantial cross-sectional variation in house price changes at the state level as an instrumental variable. We find the marginal propensity to consume out of unexpected housing wealth changes to be seven cents per dollar, a figure that is broadly consistent with a basic prediction from a life-cycle model: with a 30 -year planning horizon and a $3 \%$ real interest rate, a life-cycle model would predict a change in spending of $5 \%$ of an unexpected wealth shock (Poterba, 2000). Our estimate, which is based on household-level total spending and wealth, is consistent with a number of estimates based on aggregate data, and with that of Mian et al. (2013), which is based on zip- and county-level data on auto sales and credit card purchases. Considering the differences in data and approach, the similarities should increase confidence in the numerical magnitude. A marginal propensity to consume of 0.07 out of housing wealth would have led to declines in spending during the recession that, in some cases, would have been substantial: in California a decline in house value of $\$ 100,000$ was not unusual, and that would have caused a reduction in spending of $\$ 7,000$. Such large reductions in spending may have contributed to the instability in the macro economy.

With respect to financial wealth, we estimate a relatively smaller marginal propensity to consume of about 0.04 with a p-value of 0.052 based on a grouping method. Finding a statistically significant effect faced difficulties ex ante. Most households do not hold stocks: outside of pension accounts, the rate of stock holding among those over the age of 50 is just $29 \%$. Including pension accounts would increase this percentage, but households may not view pension 
accounts as having the same immediate impact on spending as other accounts. Further, among those who do hold stocks, holdings are highly skewed: just $55 \%$ of households who own stocks have holdings of more than $\$ 50,000$. Thus the need of most households to adjust spending in response to a stock wealth shock is limited. The estimation method we used for changes in housing wealth was not available to us for estimation of responses to changes in financial wealth: the former relied on locational differences to produce differences in housing price changes; no such variation is available for stock price changes. Nonetheless, holders of stocks age 51-65 did reduce spending over the recession years by a greater amount (9\%) than would be expected from their behavior in non-recessionary periods and from the behavior of non-stockholders (Table 3). Quantifying this as a marginal propensity to consume, however, requires a reliable estimate of the change in financial wealth: because of noise in financial wealth data (especially stock market wealth), changes in financial wealth have large standard errors, which we smoothed out by a grouping method; nonetheless the means retained considerable variance.

We document that sensitivity to wealth shocks, both in housing and stock wealth, varies with age. For example, spending declined significantly among those 51-65 in response to both housing and stock wealth shocks, but less so among those 66-90 (Tables 3 and 4). Reactions to wealth shocks depend on portfolio composition, life-cycle position, the ability to adjust consumption and the cost of doing so, and the ability to adjust along other (non-spending) dimensions. The most obvious difference between the younger and older groups is that the former is mostly still engaged in market work: an alternative to reducing consumption following a wealth shock is to work longer, but it may be that the weak job market made them wary of relying on working longer to make up for the loss. Older households are in receipt of Social Security and pension benefits, which they may perceive as more secure than are younger households, which are not yet in receipt. By the logic of the lifetime budget constraint, a wealth shock must be financed out of reduced consumption (including intervivos transfers) or by reduced bequests. Because of time horizon differences, the older group may view bequests as the relevant margin for 
adjustment and thus reduce expected bequests rather than consumption.

In summary, we find that consumption was reduced in the Great Recession because of losses in housing wealth. We provide suggestive evidence of a consumption reduction from financial wealth loss, although this effect is not precisely estimated. Nonetheless, both findings suggest feedbacks from wealth loss to spending reductions that could have acted to exacerbate the recession.

\section{References}

Attanasio, O. P., L. Blow, R. Hamilton, and A. Leicester (2009). Boom and busts: consumption, house prices and expectations. Economica 76, 20-50.

Attanasio, O. P. and G. Weber (1995). Is consumption growth consistent with intertemporal optimization? Evidence from the consumer expenditure survey. Journal of Political Economy 103, 1121-1157.

Banks, J., R. Crawford, T. F. Crossley, and E. C. (2013). Financial crisis wealth losses and responses among older households in England. Fiscal Studies 34, 231-254.

Bostic, R., S. Gabriel, and G. Painter (2009). Housing wealth, financial wealth, and consumption: new evidence from micro data. Regional Science and Urban Economics 39, 79-89.

Bottazzi, R., S. Trucchi, and M. Wakefield (2013). Wealth effects and the consumption of Italian households in the Great Recession. Institute for Fiscal Studies Working Paper W13/21.

Browning, M., T. F. Crossley, and G. Weber (2009). Shocks, stocks and socks: smoothing consumption over a temporary income loss. Journal of the European Economic Association 7(6).

Browning, M. and E. Madsen (2005). Consumption. In A. Börsch-Supan and K. Alcser (Eds.), Health, Ageing and Retirement in Europe: First Results 
from the Survey of Health, Ageing and Retirement in Europe. Mannheim: Mannheim Research Institute for the Economics of Aging.

Campbell, J. Y. (1987). Does saving anticipate declining labor income? An alternative test of the permanent income hypothesis. Econometrica 55(6).

Campbell, J. Y. and J. F. Cocco (2007). How do house prices affect consumption? Evidence from micro data. Journal of Monetary Economics $54(3)$.

Campbell, J. Y. and N. G. Mankiw (1989). Consumption, income, and interest rates: reinterpreting the time series evidence. In O. J. Blanchard and S. Fisher (Eds.), NBER Macroeconomics Annual 1989, Volume 4. Cambridge, MA: MIT Press.

Carroll, C. D., M. Otsuka, and J. Slacalek (2011). How large are housing and financial wealth effects? A new approach. Journal of Money, Credit and Banking 43(1), 5579.

Case, K. E., J. M. Quigley, and R. J. Shiller (2005). Comparing wealth effects: the stock market versus the housing market. Advances in Microeconomics 5(1), 1-32.

Case, K. E., J. M. Quigley, and R. J. Shiller (2013). Wealth effects revisited 1975-2012. Critical Finance Review 2(1), 101-128.

Christelis, D., D. Georgarakos, and T. Jappelli (2015). Wealth shocks, unemployment shocks and consumption in the wake of the Great Recession. Journal of Monetary Economics, forthcoming.

Engelhardt, G. V. (1996). House prices and home owner saving behavior. Regional Science and Urban Economics 26(3), 313-336.

Flavin, M. A. (1981). The adjustment of consumption to changing expectations about future income. The Journal of Political Economy, 974-1009.

Hansen, L. P. and K. J. Singleton (1983). Stochastic consumption, risk aversion, and the temporal behavior of asset returns. The Journal of Political Economy, 249-265. 
Hudomiet, P., G. Kézdi, and R. J. Willis (2011). Stock market crash and expectations of American households. Journal of Applied Econometrics 26(3), 393-415.

Hurd, M. D., D. McFadden, H. Chand, L. Gan, A. Menill, and M. Roberts (1998). Consumption and savings balances of the elderly: experimental evidence on survey response bias. In A. D. Wise (Ed.), Frontiers in the Economics of Aging, pp. 353-392. Chicago, IL: University of Chicago Press.

Hurd, M. D. and S. Rohwedder (2009). Methodological innovations in collecting spending data: the HRS consumption and activities mail survey. Fiscal Studies 30(3-4), 435-459.

Hurd, M. D. and S. Rohwedder (2015). Wealth dynamics and active saving at older ages. In C. D. Carroll, T. F. Crossley, and J. Sabelhaus (Eds.), Improving the Measurement of Consumer Expenditures, Studies in Income and Wealth, Vol. 74, pp. forthcoming. Chicago, IL: University of Chicago Press.

Juster, F. T., J. P. Lupton, J. P. Smith, and F. Stafford (2006). The decline in household saving and the wealth effect. Review of Economics and Statistics 88(1), 20-27.

McInerney, M., J. M. Mellor, and L. H. Nicholas (2013). Recession depression: mental health effects of the 2008 stock market crash. Journal of Health Economics 32(6), 1090-1104.

Mian, A. R., K. Rao, and A. Sufi (2013). Household balance sheets, consumption, and the economic slump. Quarterly Journal of Economics 128, $1687-1726$.

Mian, A. R. and A. Sufi (2011). House prices, home equity-based borrowing, and the US household leverage crisis. The American Economic Review 101, 2132-2156. 
Morris, E. D. (2006). Examining the wealth effect from home price appreciation. University of Michigan, mimeo.

Paiella, M. (2009). The stock market, housing and consumer spending: a survey of the evidence on wealth effects. Journal of Economic Surveys 23(5), $947-973$.

Poterba, J. M. (2000). Stock market wealth and consumption. The Journal of Economic Perspectives, 99-118.

Sierminska, E. and Y. Takhtamanova (2007). Wealth effects out of financial and housing wealth: cross country and age group comparisons. Federal Reserve Bank of San Francisco, Working Paper (2007-01).

Slacalek, J. (2009). What drives personal consumption? The role of housing and financial wealth. The BE Journal of Macroeconomics 9(1).

Souleles, N. S. (1999). The response of household consumption to income tax refunds. The American Economic Review 89(4), 947-958. 


\section{A Appendix}

\section{A.1 Design Features of the CAMS Questionnaire on Spending}

Survey mode: self-administered.

The CAMS is a paper-and-pencil survey that is sent to respondents in the mail. As such it is a self-administered survey where respondents can take the time they need and are willing to spend to fill out the questionnaire. They can consult records or other household members to help gather the information. This is important because producing informative reports about the amounts spent on certain categories usually requires some thought and respondents would not take this time if an interviewer was waiting for the answer in real time.

Level of aggregation: 39 categories.

The level of aggregation was chosen to balance respondent burden on the one hand and prompting respondents' memories sufficiently about different categories of spending on the other hand so that they will not forget to report anything. For example, asking just one or just a hand-full of questions about spending would lead to substantial underreporting of spending. See for example Hurd et al. (1998) who document the extent of underreporting of a one-shot spending question, and Browning and Madsen (2005) who assess the degree of underreporting and data quality when asking four spending questions. The U.S. Consumer Expenditure Survey asks about spending in several hundred categories which would not be feasible in a general household survey and would also not necessarily produce more accurate data. CAMS queries households about their spending in a total of 39 categories. They are listed below.

Length of reference period: adapted to spending category; offering choice for some categories.

The shorter the reference period the smaller the recall error. However, the objective in CAMS is to measure annual total household spending. If house- 
holds spent the same amount every day on all categories then it would be sufficient to ask households for what they spent "yesterday" and to multiply that amount by 365 . Instead there are some categories that tend to be recurring every month or every week, others are more irregular. This suggests that for obtaining annual spending the reference period should be "last 12 months" for irregular spending categories, like trips and vacations or home repairs, and "last month" or "monthly" for spending categories that are recurring every month, like utilities. This is the approach adopted in CAMS. For those categories where there is likely variation across households in the frequency of spending in some categories CAMS offers respondents the choice of reporting their spending "last month/monthly" or "last 12 months" whichever "best reflects the households spending."

\section{A.2 List of CAMS spending categories}

\section{Purchases of big ticket items in the past twelve months:}

Automobile or truck; Refrigerator; Washing machine and/or dryer; Dishwasher; Television; Computer.

\section{Amount spent in last 12 months:}

Homeowners or renters insurance; Property taxes; Vehicle insurance; Vehicle maintenance: parts, repairs, and servicing; Health insurance: out-of-pocket, including Medicare supplemental insurance; Trips and vacations: including transportation, accommodations, and recreational expenses on trips; Home repairs and maintenance: materials your household bought directly; Home repairs and maintenance services: hiring costs including materials they provided; Household furnishings and equipment: such as furniture, floor coverings, small appliances, miscellaneous household equipment; Contributions to religious, educational, charitable, or political organizations; Cash or gifts to family and friends outside your household: including alimony and child support payments.

Amount spent "monthly" or in last 12 months:

Mortgage; Rent; Electricity; Water; Heating fuel for the home; Telephone, 
cable, internet; Car payments: interest and principal.

Amount spent "monthly" or "in last 12 months" please use the time period that best reflects your spending over the last 12 months: Housekeeping supplies: cleaning and laundry products; Housekeeping, dry cleaning and laundry services: hiring costs for housekeeping or home cleaning, and amount spent at dry cleaners and laundries; Gardening and yard supplies: yard, lawn and garden products; Gardening and yard services: hiring costs including materials they provided; Clothing and apparel: including footwear, outerwear, and products such as watches or jewelry; Personal care products and services: including hair care, shaving and skin products, amount spent at hair dresser, manicure, etc.; Prescription and nonprescription medications: out-of- pocket cost, not including what is covered by insurance; Health care services: out-of-pocket cost of hospital care, doctor services, lab tests, eye, dental, and nursing home care; Medical supplies: out-of-pocket cost, not including what is covered by insurance; Tickets to movies, sporting events, and performing arts; Sports: including gym, exercise equipment such as bicycles, skis, boats, etc.; Hobbies and leisure equipment: such as photography, stamps, reading materials, camping, etc.

Amount spent "weekly," "monthly," or "last 12 months" whichever is easiest to report:

Food and beverages: food and drinks, including alcoholic, that you buy in grocery or other stores; Dining and/or drinking out: items in restaurants, cafes, and diners, including take- out food; Gasoline.

\section{A.3 Descriptives: Changes in Household Wealth and Spending}

Table A1 shows average levels of self-reported house values and changes in those levels between adjacent waves for homeowners grouped into three categories according to house price inflation in the state of residence, as measured by the FHFA index. Specifically, we calculate, state by state, the percentage decline in house prices during the Great Recession (following the NBER 
definition this goes from 2007q4 to 2009q3) and assign each household to one of three groups corresponding to the terciles of the distribution of state-level price declines. Among households in the first tercile, mean self-reported housing wealth (in 2011 dollars) was about $\$ 147,000$ averaged over the years 2003 , 2005 , and 2009, and about $\$ 149,000$ averaged over the years 2005,2007 , and 2011. This implies a two-year rate of growth in non-recessionary periods of $1.46 \%$. For the same group, mean housing wealth was about $\$ 156,000$ in 2007 and $\$ 160,000$ in 2009 , implying a two-year rate of growth in recessionary times of $3.13 \%$. Thus the growth rate in self-reported house values among households in the 17 states with the smallest house price declines was approximately the same during the recession as the average before and after the recession. In contrast, households in the third tercile experienced almost no change in house values in non-recessionary times, but home values dropped by almost $9 \%$ during the crisis. Differences-in-differences computations show that, relative to non-recessionary times, changes in house values in the recession experienced by homeowners in states in the third tercile were about 11 percentage points greater than changes among homeowners in the first tercile and the difference is statistically significant. ${ }^{20} \mathrm{~A}$ possible source of contamination of these differences is migration across state borders between waves, possibly causing changes in the composition of the terciles. But between-state mobility is uncommon in our sample: just $1 \%$ of the respondents switched tercile groups between 2006 and 2010, and only $2 \%$ did so over the entire decade 2002-2012. ${ }^{21}$

Table A2 documents changes in household financial wealth between two adjacent waves. Financial wealth is defined as the sum of the self-reported value of stocks, bonds, CDs, and checking and savings accounts. To capture the differential effect of the Great Recession across households with different

\footnotetext{
${ }^{20}$ The fact that the self-reported declines in house values in the HRS are larger in the third tercile than in the second, and larger in the second than in the first increases our confidence in the accuracy of the self-reports: the tercile rankings are derived from FHFA price statistics, not from the self-reports.

${ }^{21}$ Our results are robust to excluding those respondents who moved from one state to another.
} 
Table A1: Mean Housing Wealth by Terciles of House Price Decline during the Great Recession

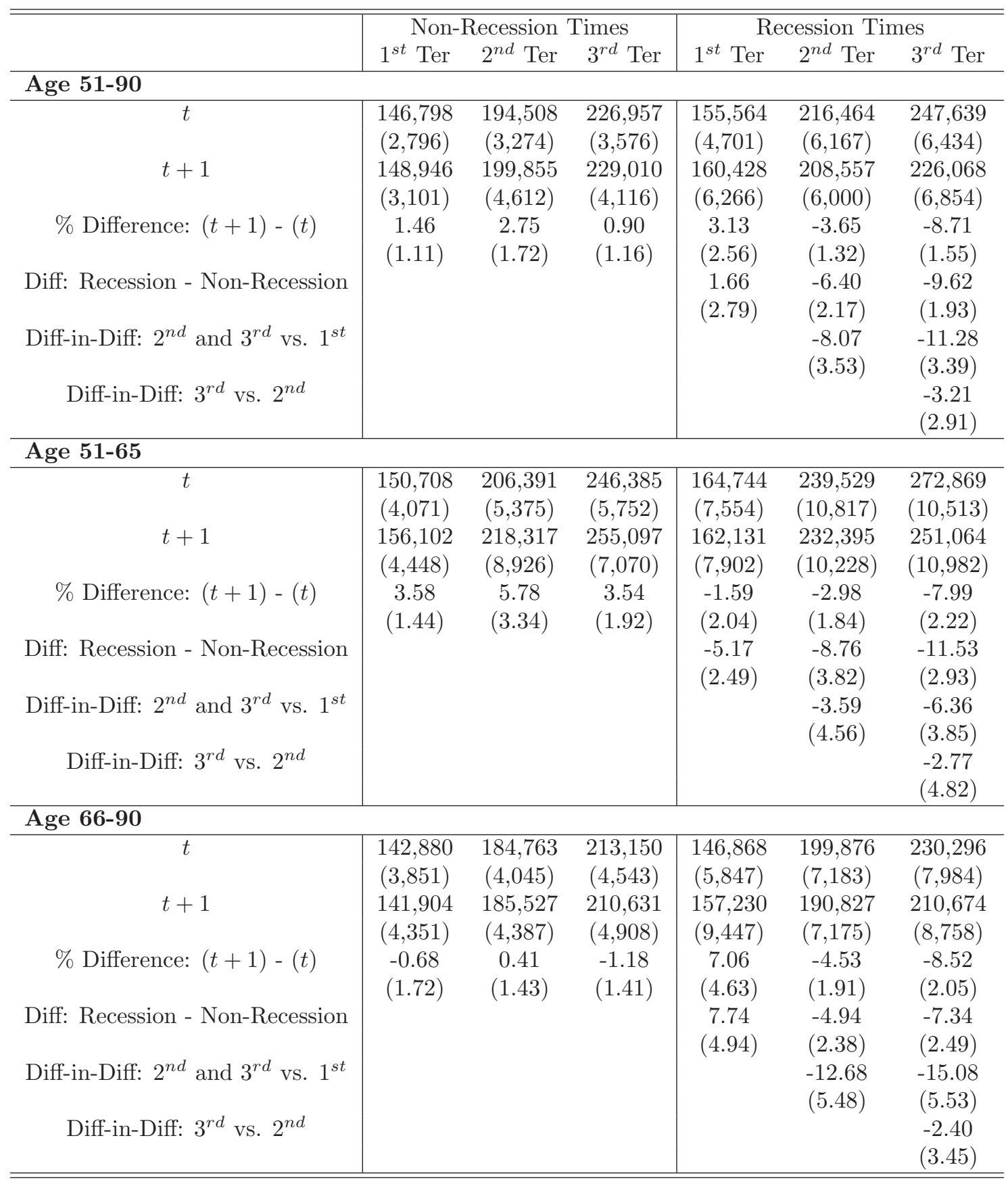

Terciles are defined at the state level: the first and third terciles comprise the 17 states with the smallest and largest house price declines from 2007q4 to 2009q2, respectively. Delta Method standard errors in parentheses. Housing wealth is the value of the primary residence (in 2011 dollars) at the time of the HRS interview brought forward to the time of the CAMS interview using house price changes at the state level. In each survey wave we drop households with housing wealth in the top $1 \%$ or bottom $1 \%$ of the sample. For non-recession times, $t=2003 ; 2005 ; 2009$ and $t+1=2005 ; 2007 ; 2011$. For recession theses $t=2007$ and $t+1=2009$. The computations only include households observed in both time $t$ and $t+1$. 
Table A2: Mean Financial Wealth by Stock Ownership

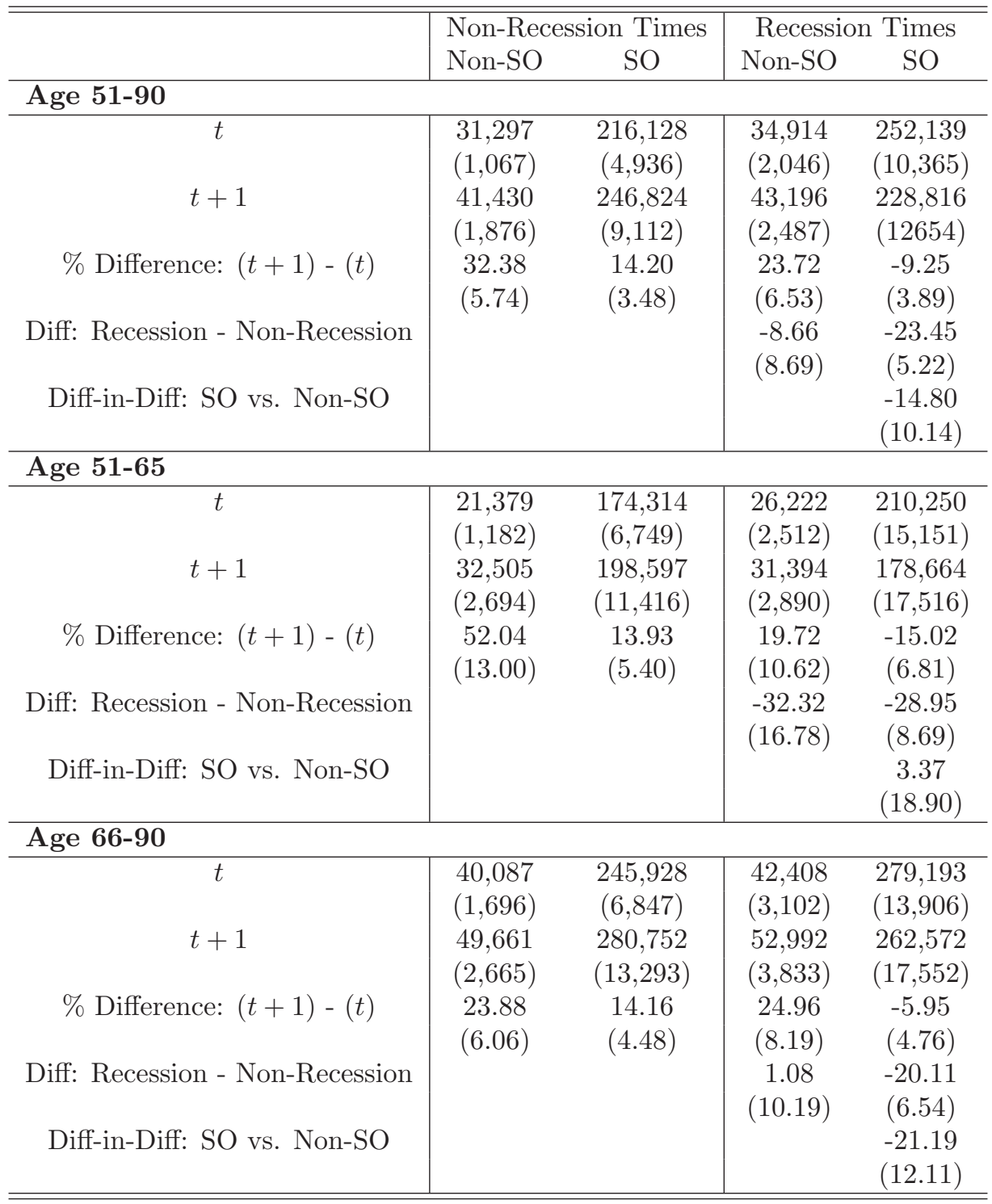

SO: Stockowners; Non-SO: Non-Stockowners. Delta Method standard errors in parentheses. Financial wealth is defined as the sum of stocks, bonds, CDs, T-Bills and checking/saving accounts at the time of the HRS interview. The value of stocks is brought forward to the time of the CAMS interview using changes in the S\&P500 index; the value of bonds is brought forward to the time of the CAMS interview using changes in the Merrill Lynch U.S. Corp Master Total Return Index; the value of CDs, T-Bills and checking/saving accounts is brought forward to the time of the CAMS interview using changes in the interest rate. Values are in 2011 dollars. In each survey wave we drop households with financial wealth in the top $1 \%$ or bottom $1 \%$ of the sample. For non-recession times, $t=2003 ; 2005 ; 2009$ and $t+1=2005 ; 2007 ; 2011$. For recession times $t=2007$ and $t+1=2009$. The computations only include households observed in both time $t$ and $t+1$. 
portfolios, we stratify respondents by stock ownership vs. non-ownership in the initial wave (e.g., stock ownership at time $t$ for wealth changes between time $t$ and $t+1$ ). Because of the sharp decline in stock prices between 2007 and 2009, we expected stockowners to report larger negative changes in financial wealth than non-stockowners during the recessionary period. Since the crisis may have induced individuals to reallocate wealth across financial asset categories, we focus on the value of total financial wealth rather than on the value of stock wealth (which should have been more directly affected by the stock market crash).

Table A2 shows mean financial wealth levels and changes in those levels between adjacent waves by stock ownership. Among households not owning stocks in the baseline wave, mean financial wealth (in 2011 dollars) is about $\$ 31,000$ averaged over the years 2003, 2005, and 2009, and about $\$ 41,000$ averaged over the years 2005, 2007, and 2011. Financial wealth is much lower among non-stockowners than among stock owners, and its growth is less marked in recessionary than in non-recessionary times (almost 9 percentage points less). Among stockowners, the two-year rate of growth of financial wealth is $-9.25 \%$ during recessionary times, about 23 percentage points less than the average during non-recessionary times. Differences-in-differences computations show that, as expected, stockowners lost more financial wealth because of the financial crisis than non-stockowners. The difference is roughly 15 percentage points, although statistically significant only at the $15 \%$ level. Table A2 also documents heterogeneity by age, with younger investors experiencing more sizeable changes than their older counterparts. Among stockowners age 51-65 financial wealth decreased by 15\% during the recession, while the wealth of older stockowners declined by just $6 \%$.

Tables A3 and A4 convey qualitatively the same information as Tables 1 and 2 except that they show averages of household spending changes rather than changes in household spending averages. 
Table A3: Percentage Changes in Spending: All and by Asset Ownership

\begin{tabular}{|c|c|c|c|c|c|}
\hline & All & Non-HO & $\mathrm{HO}$ & Non-SO & $\mathrm{SO}$ \\
\hline \multicolumn{6}{|l|}{ Age 51-90 } \\
\hline Non-Recession Times & $\begin{array}{l}-6.51 \\
(0.50)\end{array}$ & $\begin{array}{l}-7.89 \\
(1.14)\end{array}$ & $\begin{array}{l}-6.19 \\
(0.55)\end{array}$ & $\begin{array}{l}-7.22 \\
(0.61)\end{array}$ & $\begin{array}{l}-5.06 \\
(0.85)\end{array}$ \\
\hline Recession Times & $\begin{array}{l}-7.50 \\
(0.80)\end{array}$ & $\begin{array}{l}-3.74 \\
(1.99)\end{array}$ & $\begin{array}{l}-8.38 \\
(0.87)\end{array}$ & $\begin{array}{l}-6.65 \\
(0.97)\end{array}$ & $\begin{array}{c}-9.42 \\
(1.39)\end{array}$ \\
\hline Diff: Recession - Non-Recession & $\begin{array}{l}-1.00 \\
(0.94)\end{array}$ & $\begin{array}{c}4.15 \\
(2.29)\end{array}$ & $\begin{array}{l}-2.19 \\
(1.03)\end{array}$ & $\begin{array}{c}0.57 \\
(1.15)\end{array}$ & $\begin{array}{c}-4.37 \\
(1.64)\end{array}$ \\
\hline Diff-in-Diff: HO vs. Non-HO & & & $\begin{array}{l}-6.33 \\
(2.51)\end{array}$ & & \\
\hline Diff-in-Diff: SO vs. Non-SO & & & & & $\begin{array}{l}-4.94 \\
(2.00)\end{array}$ \\
\hline \multicolumn{6}{|l|}{ Age 51-65 } \\
\hline Non-Recession Times & $\begin{array}{l}-5.53 \\
(0.76)\end{array}$ & $\begin{array}{l}-7.08 \\
(1.89)\end{array}$ & $\begin{array}{l}-5.21 \\
(0.83)\end{array}$ & $\begin{array}{l}-7.28 \\
(0.93)\end{array}$ & $\begin{array}{c}-1.71 \\
(1.31)\end{array}$ \\
\hline Recession Times & $\begin{array}{l}-9.07 \\
(1.22)\end{array}$ & $\begin{array}{l}-3.80 \\
(3.15)\end{array}$ & $\begin{array}{c}-10.18 \\
(1.32)\end{array}$ & $\begin{array}{l}-7.82 \\
(1.47)\end{array}$ & $\begin{array}{r}-12.00 \\
(2.16)\end{array}$ \\
\hline Diff: Recession - Non-Recession & $\begin{array}{l}-3.54 \\
(1.44)\end{array}$ & $\begin{array}{c}3.29 \\
(3.67)\end{array}$ & $\begin{array}{l}-4.96 \\
(1.56)\end{array}$ & $\begin{array}{l}-0.54 \\
(1.74)\end{array}$ & $\begin{array}{c}-10.29 \\
(2.53)\end{array}$ \\
\hline Diff-in-Diff: HO vs. Non-HO & & & $\begin{array}{l}-8.25 \\
(3.99)\end{array}$ & & \\
\hline Diff-in-Diff: SO vs. Non-SO & & & & & $\begin{array}{c}-9.75 \\
(3.07)\end{array}$ \\
\hline \multicolumn{6}{|l|}{ Age 66-90 } \\
\hline Non-Recession Times & $\begin{array}{l}-7.21 \\
(0.66)\end{array}$ & $\begin{array}{l}-8.46 \\
(1.45)\end{array}$ & $\begin{array}{l}-6.90 \\
(0.74)\end{array}$ & $\begin{array}{l}-7.18 \\
(0.82)\end{array}$ & $\begin{array}{c}-7.25 \\
(1.13)\end{array}$ \\
\hline Recession Times & $\begin{array}{l}-6.58 \\
(1.07)\end{array}$ & $\begin{array}{l}-4.08 \\
(2.60)\end{array}$ & $\begin{array}{c}-7.19 \\
(1.17)\end{array}$ & $\begin{array}{l}-6.07 \\
(1.31)\end{array}$ & $\begin{array}{l}-7.68 \\
(1.83)\end{array}$ \\
\hline Diff: Recession - Non-Recession & $\begin{array}{c}0.62 \\
(1.26)\end{array}$ & $\begin{array}{c}4.38 \\
(2.98)\end{array}$ & $\begin{array}{l}-0.28 \\
(1.38)\end{array}$ & $\begin{array}{c}1.12 \\
(1.55)\end{array}$ & $\begin{array}{l}-0.43 \\
(2.15)\end{array}$ \\
\hline Diff-in-Diff: HO vs. Non-HO & & & $\begin{array}{l}-4.66 \\
(3.35)\end{array}$ & & \\
\hline Diff-in-Diff: SO vs. Non-SO & & & & & $\begin{array}{l}-1.55 \\
(2.65)\end{array}$ \\
\hline
\end{tabular}

HO: Homeowners; Non-HO: Non-Homeowners. SO: Stockowners; Non-SO: NonStockowners. Delta Method standard errors in parentheses. For non-recession times, changes in spending are computed between 2003-2005, 2005-2007 and 20092011. For recession times, changes in spending are computed between 2007-2009. The computations only include households observed in both time $t$ and $t+1$.In each survey wave we drop households with changes in spending in the top $1 \%$ or bottom $1 \%$ of the sample. 
Table A4: Percentage Changes in Spending by Terciles of House Price Decline during the Great Recession

\begin{tabular}{|c|c|c|c|}
\hline & 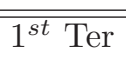 & $2^{2^{\text {nd }} \text { Ter }}$ & $\overline{3^{\text {rd }} \text { Ter }}$ \\
\hline \multicolumn{4}{|l|}{ Age 51-90 } \\
\hline Non-Recession Times & $\begin{array}{l}-7.33 \\
(0.96)\end{array}$ & $\begin{array}{l}-5.27 \\
(0.96)\end{array}$ & $\begin{array}{l}-5.92 \\
(0.94)\end{array}$ \\
\hline Recession Times & $\begin{array}{l}-3.76 \\
(1.51)\end{array}$ & $\begin{array}{l}-7.84 \\
(1.53)\end{array}$ & $\begin{array}{r}-13.10 \\
(1.46)\end{array}$ \\
\hline Diff: Recession - Non-Recession & $\begin{array}{c}3.56 \\
(1.79)\end{array}$ & $\begin{array}{l}-2.56 \\
(1.81)\end{array}$ & $\begin{array}{l}-7.18 \\
(1.74)\end{array}$ \\
\hline Diff-in-Diff: $2^{\text {nd }}$ and $3^{\text {rd }}$ vs. $1^{\text {st }}$ & & $\begin{array}{l}-6.13 \\
(2.54)\end{array}$ & $\begin{array}{r}-10.75 \\
(2.49)\end{array}$ \\
\hline Diff-in-Diff: $3^{\text {rd }}$ vs. $2^{\text {nd }}$ & & & $\begin{array}{l}-4.62 \\
(2.50)\end{array}$ \\
\hline \multicolumn{4}{|l|}{ Age 51-65 } \\
\hline Non-Recession Times & $\begin{array}{l}-6.01 \\
(1.43)\end{array}$ & $\begin{array}{l}-4.22 \\
(1.47)\end{array}$ & $\begin{array}{l}-5.35 \\
(1.41)\end{array}$ \\
\hline Recession Times & $\begin{array}{l}-5.59 \\
(2.22)\end{array}$ & $\begin{array}{l}-6.92 \\
(2.30)\end{array}$ & $\begin{array}{l}-17.77 \\
(2.28)\end{array}$ \\
\hline Diff: Recession - Non-Recession & $\begin{array}{c}0.42 \\
(2.64)\end{array}$ & $\begin{array}{l}-2.70 \\
(2.73)\end{array}$ & $\begin{array}{c}-12.42 \\
(2.68)\end{array}$ \\
\hline Diff-in-Diff: $2^{\text {nd }}$ and $3^{\text {rd }}$ vs. $1^{\text {st }}$ & & $\begin{array}{l}-3.12 \\
(3.80)\end{array}$ & $\begin{array}{r}-12.84 \\
(3.76)\end{array}$ \\
\hline Diff-in-Diff: $3^{r d}$ vs. $2^{\text {nd }}$ & & & $\begin{array}{l}-9.72 \\
(3.83)\end{array}$ \\
\hline \multicolumn{4}{|l|}{ Age 66-90 } \\
\hline Non-Recession Times & $\begin{array}{c}-8.43 \\
(1.32)\end{array}$ & $\begin{array}{c}-6.12 \\
(1.28)\end{array}$ & $\begin{array}{c}-6.22 \\
(1.26)\end{array}$ \\
\hline Recession Times & $\begin{array}{l}-2.51 \\
(2.09)\end{array}$ & $\begin{array}{l}-8.56 \\
(2.08)\end{array}$ & $\begin{array}{l}-9.93 \\
(1.90)\end{array}$ \\
\hline Diff: Recession - Non-Recession & $\begin{array}{c}5.92 \\
(2.47)\end{array}$ & $\begin{array}{l}-2.44 \\
(2.44)\end{array}$ & $\begin{array}{l}-3.70 \\
(2.28)\end{array}$ \\
\hline Diff-in-Diff: $2^{\text {nd }}$ and $3^{\text {rd }}$ vs. $1^{\text {st }}$ & & $\begin{array}{l}-8.36 \\
(3.47)\end{array}$ & $\begin{array}{l}-9.63 \\
(3.36)\end{array}$ \\
\hline Diff-in-Diff: $3^{r d}$ vs. $2^{\text {nd }}$ & & & $\begin{array}{l}-1.26 \\
(3.34)\end{array}$ \\
\hline
\end{tabular}

Terciles are defined at the state level: the first and third terciles comprise the 17 states with the smallest and largest house price declines from $2007 \mathrm{q} 4$ to $2009 \mathrm{q} 2$, respectively. Delta Method standard errors in parentheses. For non-recession times, changes in spending are computed between 2003-2005, 2005-2007 and 2009-2011. For recession times, changes in spending are computed between 2007-2009. The computations only include households observed in both time $t$ and $t+1$. In each survey wave we drop households with changes in spending in the top $1 \%$ or bottom $1 \%$ of the sample. 


\section{A.4 Diff-in-Diff Regressions: Robustness Checks}

Home and stock ownership may change as a result of the crisis. Consequently, the composition of ownership groups may differ in some important characteristics before and after the recession and introduce some bias in our differencesin-differences estimates. Specifically, for non-recessionary times, groups are formed according to asset ownership observed in the 2002 and 2004 HRS waves - collected before the onset of the crisis - as well as in the 2008 HRS wavewhich occurred in the midst of the economic turmoil. Their composition may be altered by the events of the Great Recession if only specific types of households changed ownership status in response to shocks brought about by the crisis. Here we investigate this issue and the extent to which it affects the conclusions based on our differences-in-differences comparisons. Changes in ownership status are relatively uncommon in our sample. Over the decade 2002-2012, only $8 \%$ of households changed home ownership and about $17 \%$ changed stock ownership. During the period spanning the Great Recession (2008-2010), these percentages are 3\% and 7\%, respectively. Households who switched home ownership status before the recession (2002-2006) are somewhat different from those that did so after the recession (2008-2010). In particular, while they have the same level of education and the same type of household composition, they appear to be slightly older, in better health, and more afflu-

ent. Specifically, the average household that switched home ownership status before the recession is 68 years of age, has a $25 \%$ likelihood to be in poor health, $\$ 45,000$ total income and $\$ 450,000$ total wealth. The average household that switched home ownership status after the recession is 64 years of age, has a $35 \%$ likelihood to be in poor health, $\$ 37,000$ total income, and $\$ 310,000$ total wealth. Given the limited number of households who changed homeownership in our sample, we do not expect these differences to introduce significant bias in our differences-in-differences estimates. Change in stock ownership are relatively more frequent. However, households who switched stock ownership status before the recession display very similar attributes as those who did so after the recession. More precisely, the average household that switched stock ownership status before the recession is 68 years of age, has a $25 \%$ likelihood 
to be in poor health, $\$ 46,000$ total income and $\$ 460,000$ total wealth. The average household that switched stock ownership status after the recession is 65 years of age, has a $29 \%$ likelihood to be in poor health, $\$ 47,000$ total income and $\$ 380,000$ total wealth. As a robustness check, we re-estimate equation (4) on the subsample of households that did not change home or stock ownership status between 2006 and 2010. The results of this exercise are reported in Table A5. We also repeat the estimation of equation (4) for non-homeowners (Table A6), for households that did not experience unemployment between 2006 and 2010 (Tables A7 and A8) and for households that did not change state of residence between 2006 and 2010 (Table A9).

Table A5: Diff-in-Diff: No Change in Asset Ownership

\begin{tabular}{|c|c|c|c|c|c|c|}
\hline \multirow{2}{*}{ Home Ownership } & \multicolumn{2}{|c|}{ Age $51-90$} & \multicolumn{2}{|c|}{ Age $51-65$} & \multicolumn{2}{|c|}{ Age $66-90$} \\
\hline & & & & & & \\
\hline$D_{r}$ & $\begin{array}{c}0.035 \\
(0.031)\end{array}$ & $\begin{array}{c}0.035 \\
(0.031)\end{array}$ & $\begin{array}{c}0.043 \\
(0.050)\end{array}$ & $\begin{array}{c}0.042 \\
(0.051)\end{array}$ & $\begin{array}{c}0.031 \\
(0.038)\end{array}$ & $\begin{array}{c}0.031 \\
(0.038)\end{array}$ \\
\hline Home Ownership & $\begin{array}{c}0.002 \\
0.030\end{array}$ & 0.003 & -0.069 & -0.071 & 0.052 & 0.054 \\
\hline \multirow{2}{*}{$D_{r} \times$ Home Ownership } & $-0.065^{* *}$ & $-0.065^{* *}$ & $-0.108^{* *}$ & $-0.106^{*}$ & -0.039 & -0.039 \\
\hline & $(0.033)$ & $(0.033)$ & $(0.054)$ & $(0.054)$ & $(0.041)$ & $(0.042)$ \\
\hline State Fixed Effects & No & Yes & No & Yes & No & Yes \\
\hline $\mathrm{N}$ & 9529 & 9529 & 4246 & 4246 & 5283 & 5283 \\
\hline \multicolumn{7}{|l|}{ Stock Ownership } \\
\hline$D_{r}$ & $\begin{array}{c}0.006 \\
(0.015)\end{array}$ & $\begin{array}{c}0.006 \\
(0.015)\end{array}$ & $\begin{array}{l}-0.005 \\
(0.024)\end{array}$ & $\begin{array}{l}-0.005 \\
(0.024)\end{array}$ & $\begin{array}{c}0.013 \\
(0.020)\end{array}$ & $\begin{array}{c}0.013 \\
(0.020)\end{array}$ \\
\hline \multirow[t]{2}{*}{ Stock Ownership } & 0.042 & 0.042 & 0.051 & 0.053 & 0.016 & 0.015 \\
\hline & $(0.027)$ & $(0.028)$ & $(0.041)$ & $(0.041)$ & $(0.038)$ & $(0.038)$ \\
\hline \multirow[t]{2}{*}{$D_{r} \times$ Stock Ownership } & -0.042 & -0.043 & $-0.112^{* *}$ & $-0.114^{* *}$ & -0.004 & -0.004 \\
\hline & $(0.030)$ & $(0.030)$ & $(0.047)$ & $(0.048)$ & $(0.038)$ & $(0.038)$ \\
\hline State Fixed Effects & No & Yes & No & Yes & No & Yes \\
\hline $\mathrm{N}$ & 8099 & 8099 & 3521 & 3521 & 4578 & 4578 \\
\hline
\end{tabular}

Standard errors are clustered at the household level and reported in parentheses. $* * *, * *$ and $*$ indicate significance at the $1 \%, 5 \%$ and $10 \%$ level, respectively. The sample includes only households that did not change home ownership status between 2006 and 2010. Other details as in Table 3. 
Table A6: Diff-in-Diff: Terciles of House Price Decline, Non-Homeowners

\begin{tabular}{c|c|c|c}
\hline \hline & Age 51-90 & Age 51-65 & Age 66-90 \\
\hline$D_{r}$ & 0.055 & $0.142^{*}$ & 0.004 \\
& $(0.043)$ & $(0.077)$ & $(0.051)$ \\
States $2^{\text {nd }}$ Ter & 0.086 & $0.174^{*}$ & 0.013 \\
& $(0.056)$ & $(0.097)$ & $(0.069)$ \\
States $3^{r d}$ Ter & $0.167^{* *}$ & 0.120 & $0.195^{* *}$ \\
& $(0.056)$ & $(0.093)$ & $(0.073)$ \\
$D_{r} \times$ States $2^{\text {nd }}$ Ter & 0.003 & -0.122 & 0.070 \\
& $(0.066)$ & $(0.108)$ & $(0.085)$ \\
$D_{r} \times$ States $3^{r d}$ Ter & -0.038 & -0.181 & 0.044 \\
& $(0.066)$ & $(0.116)$ & $(0.080)$ \\
\hline$D_{r} \times$ States $2^{r d}$ Ter $=$ & $\mathrm{F}=0.33$ & $\mathrm{~F}=0.26$ & $\mathrm{~F}=0.08$ \\
$D_{r} \times$ States $3^{r d}$ Ter & $\mathrm{p}$-val=0.57 & $\mathrm{p}$-val=0.61 & $\mathrm{p}$-val=0.78 \\
\hline $\mathrm{N}$ & 2036 & 808 & 1228 \\
\hline \hline
\end{tabular}

Standard errors are clustered at the household level and reported in parentheses. $* * *, * *$ and $*$ indicate significance at the $1 \%, 5 \%$ and $10 \%$ level, respectively. The sample includes only non-homeowners. Other details as in Table 4.

Table A7: Diff-in-Diff: No Unemployment Spells (I)

\begin{tabular}{|c|c|c|c|c|c|c|}
\hline \multirow{2}{*}{ Home Ownership } & \multicolumn{2}{|c|}{ Age $51-90$} & \multicolumn{2}{|c|}{ Age 51-65 } & \multicolumn{2}{|c|}{ Age $66-90$} \\
\hline & & & & & & \\
\hline$D_{r}$ & $\begin{array}{l}0.046^{*} \\
(0.028)\end{array}$ & $\begin{array}{l}0.046^{*} \\
(0.028)\end{array}$ & $\begin{array}{c}0.056 \\
(0.046)\end{array}$ & $\begin{array}{c}0.055 \\
(0.046)\end{array}$ & $\begin{array}{c}0.042 \\
(0.035)\end{array}$ & $\begin{array}{c}0.042 \\
(0.035)\end{array}$ \\
\hline \multirow[t]{2}{*}{ Home Ownership } & -0.022 & -0.022 & $-0.095^{* *}$ & $-0.093^{* *}$ & 0.026 & 0.027 \\
\hline & $(0.027)$ & $(0.027)$ & $(0.044)$ & $(0.045)$ & $(0.034)$ & $(0.035)$ \\
\hline \multirow[t]{2}{*}{$D_{r} \times$ Home Ownership } & $-0.074^{* *}$ & $-0.074^{* *}$ & $-0.113^{* *}$ & $-0.112^{* *}$ & -0.050 & -0.050 \\
\hline & $(0.030)$ & $(0.031)$ & $(0.050)$ & $(0.050)$ & $(0.038)$ & $(0.038)$ \\
\hline State Fixed Effects & No & Yes & No & Yes & No & Yes \\
\hline $\mathrm{N}$ & 10993 & 10993 & 4701 & 4701 & 6292 & 6292 \\
\hline \multicolumn{7}{|l|}{ Stock Ownership } \\
\hline \multirow[t]{2}{*}{$D_{r}$} & 0.002 & 0.002 & -0.006 & -0.006 & 0.006 & 0.007 \\
\hline & $(0.014)$ & $(0.014)$ & $(0.021)$ & $(0.021)$ & $(0.018)$ & $(0.018)$ \\
\hline \multirow[t]{2}{*}{ Stock Ownership } & $0.052^{* *}$ & $0.051^{* *}$ & $0.072^{* *}$ & $0.073^{* *}$ & 0.026 & 0.025 \\
\hline & $(0.022)$ & $(0.023)$ & $(0.034)$ & $(0.034)$ & $(0.030)$ & $(0.031)$ \\
\hline \multirow[t]{2}{*}{$D_{r} \times$ Stock Ownership } & $-0.046^{*}$ & $-0.046^{* *}$ & $-0.100^{* *}$ & $-0.100^{* *}$ & -0.010 & -0.011 \\
\hline & $(0.023)$ & $(0.023)$ & $(0.037)$ & $(0.037)$ & $(0.030)$ & $(0.030)$ \\
\hline State Fixed Effects & No & Yes & No & Yes & No & Yes \\
\hline $\mathrm{N}$ & 11028 & 11028 & 4719 & 4719 & 6309 & 6309 \\
\hline
\end{tabular}

Standard errors are clustered at the household level and reported in parentheses. $* * *, * *$ and $*$ indicate significance at the $1 \%, 5 \%$ and $10 \%$ level, respectively. The sample includes only households that did not experience unemployment between 2006 and 2010. Other details as in Table 3. 
Table A8: Diff-in-Diff: No Unemployment Spells (II)

\begin{tabular}{c|c|c|c}
\hline \hline & Age 51-90 & Age 51-65 & Age 66-90 \\
\hline$D_{r}$ & 0.027 & 0.003 & $0.048^{*}$ \\
& $(0.022)$ & $(0.032)$ & $(0.029)$ \\
States $2^{n d}$ Ter & $0.051^{*}$ & 0.001 & $0.090^{* *}$ \\
& $(0.027)$ & $(0.041)$ & $(0.038)$ \\
States $3^{r d}$ Ter & 0.012 & -0.041 & 0.053 \\
& $(0.027)$ & $(0.040)$ & $(0.037)$ \\
$D_{r} \times$ States $2^{\text {nd }}$ Ter & $-0.058^{*}$ & -0.047 & $-0.072^{*}$ \\
& $(0.031)$ & $(0.048)$ & $(0.041)$ \\
$D_{r} \times$ States $3^{r d}$ Ter & $-0.103^{* *}$ & $-0.133^{* *}$ & $-0.090^{* *}$ \\
& $(0.030)$ & $(0.046)$ & $(0.039)$ \\
\hline$D_{r} \times$ States 2 $2^{r d}$ Ter $=$ & $\mathrm{F}=2.04$ & $\mathrm{~F}=3.14$ & $\mathrm{~F}=0.21$ \\
$D_{r} \times$ States $3^{r d}$ Ter & $\mathrm{p}-\mathrm{val}=0.15$ & $\mathrm{p}-\mathrm{val}=0.08$ & $\mathrm{p}-\mathrm{val}=0.65$ \\
\hline $\mathrm{N}$ & 8994 & 3918 & 5076 \\
\hline \hline
\end{tabular}

Standard errors are clustered at the household level and reported in parentheses. ***, ** and $*$ indicate significance at the $1 \%, 5 \%$ and $10 \%$ level, respectively. The sample includes only households that did not experience unemployment between 2006 and 2010. Other details as in Table 4.

Table A9: Diff-in-Diff: Terciles of House Price Decline, No Change of State

\begin{tabular}{c|c|c|c}
\hline \hline & Age 51-90 & Age 51-65 & Age 66-90 \\
\hline$D_{r}$ & 0.024 & -0.005 & 0.047 \\
& $(0.022)$ & $(0.032)$ & $(0.029)$ \\
States $2^{\text {nd }}$ Ter & $0.053^{*}$ & 0.009 & $0.093^{* *}$ \\
& $(0.028)$ & $(0.042)$ & $(0.040)$ \\
States $3^{r d}$ Ter & 0.031 & -0.017 & $0.076^{*}$ \\
& $(0.028)$ & $(0.041)$ & $(0.039)$ \\
$D_{r} \times$ States $2^{\text {nd }}$ Ter & -0.050 & -0.033 & -0.067 \\
$D_{r} \times$ States $3^{r d}$ Ter & $(0.031)$ & $(0.048)$ & $(0.042)$ \\
& $-0.106^{* *}$ & $-0.142^{* *}$ & $-0.090^{* *}$ \\
$D_{r} \times$ States $2^{r d}$ Ter $=$ & $(0.030)$ & $(0.046)$ & $(0.040)$ \\
$D_{r} \times$ States $3^{r d}$ Ter & $\mathrm{F}=3.34$ & $\mathrm{~F}=5.29$ & $\mathrm{~F}=0.32$ \\
\hline $\mathrm{N}$ & 8510 & 3840 & 4670 \\
\hline \hline
\end{tabular}

Standard errors are clustered at the household level and reported in parentheses. $* * *, * *$ and $*$ indicate significance at the $1 \%, 5 \%$ and $10 \%$ level, respectively. The sample includes only households that did not change state of residence between 2006 and 2010. Other details as in Table 4. 


\section{A.5 First-Stage and Reduced-Form Results}

Table A10 below shows the first-stage results and diagnostics for the IV regressions using housing wealth presented in Table 5. The first-stage consists of two regressions relating the two endogenous variables $-\Delta \log (H W)$ and $D_{r} \times \Delta \log (H W)$ - to the two instruments, namely changes in state-level house price indices (HPI) during non-recession and recession times $-\Delta \log (H P I)$ and $D_{r} \times \Delta \log (H P I)$, respectively. In Table A10, we only report the estimated coefficients on $\Delta \log (H P I)$ and $D_{r} \times \Delta \log (H P I)$ and omit those associated with controls. For the Underidentification and Weak Identification Tests we report the Kleibergen-Paap rank LM and Wald F statistics, respectively.

Table A10: IV First-Stage Results

\begin{tabular}{|c|c|c|c|c|c|c|}
\hline & $(\mathrm{I})$ & (II) & (III) & (IV) & $(\mathrm{V})$ & $(\mathrm{VI})$ \\
\hline \multicolumn{7}{|c|}{ Regression for $\Delta \log (H W)$} \\
\hline$\Delta \log (H P I)$ & $\begin{array}{c}0.85^{* * *} \\
(0.03)\end{array}$ & $\begin{array}{c}0.87^{* * *} \\
(0.03)\end{array}$ & $\begin{array}{c}0.79^{* * *} \\
(0.04)\end{array}$ & $\begin{array}{c}0.80^{* * *} \\
(0.05)\end{array}$ & $\begin{array}{c}0.79^{* * *} \\
(0.04)\end{array}$ & $\begin{array}{c}0.80^{* * *} \\
(0.05)\end{array}$ \\
\hline$D_{r} \times \Delta \log (H P I)$ & $\begin{array}{c}-0.39 * * * \\
(0.05)\end{array}$ & $\begin{array}{c}-0.41^{* * *} \\
(0.07)\end{array}$ & $\begin{array}{c}-0.36^{* * *} \\
(0.06)\end{array}$ & $\begin{array}{c}-0.38^{* * *} \\
(0.07)\end{array}$ & $\begin{array}{c}-0.36^{* * *} \\
(0.06)\end{array}$ & $\begin{array}{c}-0.37^{* * *} \\
(0.07)\end{array}$ \\
\hline \multicolumn{7}{|c|}{ Regression for $D_{r} \times \Delta \log (H W)$} \\
\hline$\Delta \log (H P I)$ & $\begin{array}{c}0.00 \\
(0.00)\end{array}$ & $\begin{array}{c}0.01 \\
(0.00)\end{array}$ & $\begin{array}{c}0.00 \\
(0.01)\end{array}$ & $\begin{array}{c}0.01 \\
(0.01)\end{array}$ & $\begin{array}{c}0.00 \\
(0.01)\end{array}$ & $\begin{array}{c}0.01 \\
(0.01)\end{array}$ \\
\hline$D_{r} \times \Delta \log (H P I)$ & $\begin{array}{c}0.46^{* * *} \\
(0.05)\end{array}$ & $\begin{array}{c}0.44^{* * * *} \\
(0.05)\end{array}$ & $\begin{array}{c}0.46^{* * * *} \\
(0.05)\end{array}$ & $\begin{array}{c}0.44^{* * * *} \\
(0.05)\end{array}$ & $\begin{array}{c}0.46^{* * * *} \\
(0.05)\end{array}$ & $\begin{array}{c}0.44^{* * *} \\
(0.05)\end{array}$ \\
\hline \multicolumn{7}{|l|}{ First-Stage Diagnostic } \\
\hline $\begin{array}{l}\text { Underidentification Test } \\
(\mathrm{p} \text {-val) }\end{array}$ & $\begin{array}{c}\chi^{2}=82.5 \\
(0.00)\end{array}$ & $\begin{array}{c}\chi^{2}=78.0 \\
(0.00)\end{array}$ & $\begin{array}{c}\chi^{2}=114.9 \\
(0.00)\end{array}$ & $\begin{array}{c}\chi^{2}=85.1 \\
(0.00)\end{array}$ & $\begin{array}{c}\chi_{1}^{2}=115.5 \\
(0.00)\end{array}$ & $\begin{array}{c}\chi^{2}=85.5 \\
(0.00)\end{array}$ \\
\hline $\begin{array}{l}\text { Weak Identification Test } \\
(\mathrm{p} \text {-val })\end{array}$ & $\begin{array}{c}F=44.6 \\
(0.00)\end{array}$ & $\begin{array}{c}F=41.0 \\
(0.00)\end{array}$ & $\begin{array}{c}F=61.0 \\
(0.00)\end{array}$ & $\begin{array}{c}F=43.9 \\
(0.00)\end{array}$ & $\begin{array}{c}F=61.3 \\
\quad(0.00)\end{array}$ & $\begin{array}{c}F=44.1 \\
\quad(0.00)\end{array}$ \\
\hline State Fixed Effects & No & Yes & No & Yes & No & Yes \\
\hline $\mathrm{N}$ & 8621 & 8621 & 8621 & 8621 & 8621 & 8621 \\
\hline
\end{tabular}

Standard errors are clustered at the household level and reported in parentheses if not otherwise specified. $\chi^{2}$ is $\chi_{1}^{2} ; F$ is $F_{2,3105}{ }^{* * *},{ }^{* *}$ and ${ }^{*}$ indicate significance at the $1 \%, 5 \%$ and $10 \%$ level, respectively. Other details as in Table 5 . 
Table A11: Reduced-Form Regressions

\begin{tabular}{c|c|c|c|c|c|c}
\hline \hline & $(\mathrm{I})$ & $(\mathrm{II})$ & $(\mathrm{III})$ & $(\mathrm{IV})$ & $(\mathrm{V})$ & $(\mathrm{VI})$ \\
\hline$\Delta \log (H P I)_{n r}$ & -0.033 & -0.029 & -0.030 & -0.023 & -0.030 & -0.022 \\
& $(0.035)$ & $(0.037)$ & $(0.056)$ & $(0.062)$ & $(0.056)$ & $(0.062)$ \\
$\Delta \log (H P I)_{r}$ & $0.208^{* *}$ & $0.201^{* *}$ & $0.204^{* *}$ & $0.195^{*}$ & $0.201^{* *}$ & $0.192^{*}$ \\
& $(0.076)$ & $(0.097)$ & $(0.079)$ & $(0.102)$ & $(0.079)$ & $(0.102)$ \\
State Fixed Effects & No & Yes & No & Yes & No & Yes \\
\hline $\mathrm{N}$ & 8621 & 8621 & 8621 & 8621 & 8621 & 8621 \\
\hline \hline
\end{tabular}

Standard errors are clustered at the household level and reported in parentheses. $* * *, * *$ and $*$ indicate significance at the $1 \%, 5 \%$ and $10 \%$ level, respectively. Other details as in Table 5 .

Table A12: Housing Wealth Elasticity and MPC: No Unemployment Spells

\begin{tabular}{|c|c|c|c|c|c|c|}
\hline & (I) & (II) & (III) & $(\mathrm{IV})$ & $(\mathrm{V})$ & (VI) \\
\hline \multicolumn{7}{|l|}{ Elasticity } \\
\hline$\epsilon_{n r}$ & $\begin{array}{c}-0.056 \\
(0.042)\end{array}$ & $\begin{array}{l}-0.055 \\
(0.044)\end{array}$ & $\begin{array}{l}-0.063 \\
(0.072)\end{array}$ & $\begin{array}{c}-0.061 \\
(0.080)\end{array}$ & $\begin{array}{l}-0.063 \\
(0.072)\end{array}$ & $\begin{array}{l}-0.060 \\
(0.080)\end{array}$ \\
\hline$\epsilon_{r}$ & $\begin{array}{c}0.416^{* * *} \\
(0.160)\end{array}$ & $\begin{array}{c}0.433^{* *} \\
(0.208)\end{array}$ & $\begin{array}{c}0.411^{* * *} \\
(0.159)\end{array}$ & $\begin{array}{l}0.429^{* *} \\
(0.208)\end{array}$ & $\begin{array}{l}0.404^{* *} \\
(0.159)\end{array}$ & $\begin{array}{c}0.422^{* *} \\
(0.208)\end{array}$ \\
\hline \multicolumn{7}{|c|}{ Marginal Propensity to Consume } \\
\hline$M P C_{n r}$ & $\begin{array}{c}-0.012 \\
(0.010)\end{array}$ & $\begin{array}{l}-0.012 \\
(0.010)\end{array}$ & $\begin{array}{l}-0.013 \\
(0.017)\end{array}$ & $\begin{array}{c}-0.013 \\
(0.018)\end{array}$ & $\begin{array}{l}-0.013 \\
(0.017)\end{array}$ & $\begin{array}{c}-0.013 \\
(0.018)\end{array}$ \\
\hline$M P C_{r}$ & $\begin{array}{c}0.073^{* *} \\
(0.029)\end{array}$ & $\begin{array}{c}0.076^{* *} \\
(0.035)\end{array}$ & $\begin{array}{c}0.072^{* *} \\
(0.029)\end{array}$ & $\begin{array}{c}0.075^{* *} \\
(0.035)\end{array}$ & $\begin{array}{c}0.071^{* *} \\
(0.029)\end{array}$ & $\begin{array}{c}0.074^{* *} \\
(0.035)\end{array}$ \\
\hline State Fixed Effects & No & Yes & No & Yes & No & Yes \\
\hline $\mathrm{N}$ & 8505 & 8505 & 8505 & 8505 & 8505 & 8505 \\
\hline
\end{tabular}

Standard errors are clustered at the household level and reported in parentheses. Standard errors for estimated marginal propensity to consume are computed by bootstrap using 500 replications. ${ }^{* * *},{ }^{* *}$ and ${ }^{*}$ indicate significance at the $1 \%, 5 \%$ and $10 \%$ level, respectively. The sample includes only households that did not experience unemployment between 2006 and 2010. Other details as in Table 5. 